\title{
BORDERS AS AN INTERDISCPLINARY PROBLEM: TERRITORIALITY AND IDENTITY - PAST AND PRESENT
}

Summary: $\quad$ This article deals with the concepts of space and territoriality in law and politics seen through reflexion on borders, which are understood primarily as forms of identification and the basis for nation-building. While in the classical antiquity, borders were seen as exclusionary defensive structures, in modern international law in the 18th and 19th centuries, they became spaces for the delimitation of states sovereign territories. The author attempts to enligthen the symbolic significance of borders in modern European history, which have been connected with imperial designs, nationalist discourses and political imaginaries. Border rhetoric often emphasised territorial inclusions and exclusions relied to the concepts such as sovereignty, security and natural living space ("natural borders"). The concept of borders is also related to the understanding of the division of Earth's surface into areas defined as regions. Regions may construct and transcend natural and political borders. Although, borders have been through world history sites of conflict, they also build ways of interconnections between locals and neighbours. The struggle over cultural and political domination and attempts to integrate and assimilate border populations were mostly reflected into deliberate linguistic policies relating to the language of administration and the public sphere. After the Second world war, the perception of borders have changed and the new understanding of borders have prevailed, based upon the idea of cooperation and the recognition of local traditions and minority rights. The principle of uti possidetis iuris was applied in order to prevent redrawing of the borders of new states and to maintain the territorial stability of the regions. But the recent migration crisis and security concerns in Europe and America have re-actualised the perception of state borders as defensive structures. Moreover, introduction of new technologies, such as ICT and the bio-metric, have transformed classical, linear forms of territorial border surveillance into mechanisms of remote control and ruling at a distance.

Keywords: $\quad$ borderlands, diplomacy, ethnicity, frontiers (state), geopolitics, identity, maritime boundaries, sociology of law, space, territory, symbolic politics

Duško Vrban, PhD, associate professor (retired), Faculty of Law, Josip Juraj Strossmayer University of Osijek. Residence: Jože Gabrovšeka 5, 51000 Rijeka, Republic of Croatia. E-mail address: dusko.vrban@gmail.com. ORCID: https://orcid.org/00000002-5621-2067. 


\section{INTRODUCTION}

1.1. From the point of view of the traditional state theory (Staatslehre), territory is one of the basic elements of the state and the creation and delimitation of its space, remains one of basic supports for its identity in international law. In other words, states cannot be conceived outside the concept of territoriality and exercise of their sovereignty inside their borders. Also the concepts of power and authority are deeply rooted in the idea of state's territory which shapes the practices of governance. Territoriality in this sense is closely related to the concept of state borders, which constitute and represent differences in space. ${ }^{1}$ Territorial dimension of states and its relevance for the idea of sovereignty and that of international relations is a subject of the broad discipline which can be conveniently called "border studies". They include various perspectives and approaches from legal science, political geography, geopolitics, to history, anthropology and sociology. Similarly to the perspective developed in older geopolitics and a contemporary political geography, borders are also studied in the new discipline of "strategic geography" (Lozančić \& Fuerst-Bjeliš, 2017).

1.2. In the antiquity, borders were sometimes conceived as mythical constructs such as the Pillars of Hercules, but mainly as the delimitations between civilisation and barbarism. As such, they separated two distinct spaces; pacified order embodied in Greek polis and in Roman imperium, and the other one, a reign of wilderness, chaos and of quarrelsome disorder. These two distinct spaces have to be kept separated and protected by natural and artificial barriers, such as rivers, mountain ranges, sea and eventually by the walls. ${ }^{2}$ It is only with the development of international law in the 18th and 19th centuries that spaces beyond the border became neighbouring sovereign territories, implying mutual recognition and exchange in the times of peace. ${ }^{3}$ Before that time, as historical research demonstrates, borders were essentially "local artifact(-s), a tangible and public sign(-s) that indicated the limits of power not in any schematic way but through the marker's presence itself". ${ }^{4}$ It is only after the end of the 18th centuries, that state and internal administrative borders were constructed through deliberate delineations, what made them also available for the statistical and land surveys.

Nowadays, the term "border" has different meanings and it primarily refers to the physical (material) barrier, which is delineated and constructed. In a wider sense, it can be seen also as an imaginary, social and symbolic dividing line or obstacle and in this sense, the term "boundary" seems more appropriate. ${ }^{5}$ For state borders on the sea, the term "maritime boundaries" is con-

1 Cf. H. Van Houtum: The geopolitics of borders and boundaries, Geopolitics, 10, 2005, pp. 672-679, p. 672.

2 For the conception of borders in a antiquity, cf. M. Sordi (ed.): Il confine nel mondo classico, Milano, Vita e pensiero, 1987 and related remarks by R. M. Dainotto (Does Europe have a south?: An essay on borders, The Global South, vol. 5, Spring 2011, 1:3750.) Hadrian's Wall and the Antonine Wall are the most famous Roman walls, named as such for two Roman emperors, Hadrian and Antoninus Pius. They were build in the A. D. 120-s across northern England which belonged to the Roman province of Britain, and consisted of fortified sites joined by a great wall, which still stands. Also in ancient China, in order to protect the state territory from invasions of nomadic tribes, a famous long wall has been constructed, which is partly preserved today, and represents one of the main sight-seeing attractions. Cf. A. Waldron: The great wall of China: From history to myth, Cambridge, 1990.

$3 C f$. in this sense Carl Schmitt's remarks in: "The Nomos of the earth in the international law of the Jus publicum Europaeum", transl., New York, Telos Press, 2003.

4 It is only after the end of the 18th centuries, that state and internal administrative borders were constructed through deliberate delineations, what made them also available for the statistical and land surveys. 
veniently used. Such political borders are conveniently called "frontiers" (Fr.: frontière; German: Staatsgrenze). ${ }^{6}$ In order to discuss the meaning of borders more precisely, we suggest to distinguish between five meanings of it: borders as physical or material barriers, borders as the spatio-legal entities (state frontiers and boundaries), thirdly, borders as limits of jurisdiction, fourth, borders seen as processes of construction of self and other in the context of space, identity and power, and finally, borders as institutions of surveillance and control. "Bordering" as a process relates in particular to symbolic politics, collective imaginations and nation-building processes.

1.3. Borders in the physical (material) sense are either natural obstacles (mountains or water spaces), or more often, artificially constructed barriers, fences, and walls, which divide socio-political space. As such, they delineate nation- states, but also sometimes different parts of cities, public and private spaces (military and security zones, gated communities, luxury resorts and similar). The well-known Berlin wall which was built in 1961 to divide East from West Berlin, is an outstanding example of the border which represented not only physical and legal-political barrier, but also had a wider ideological and symbolic significance. ${ }^{7}$

1.4. When understood as the spatio-legal entities, or the margins of the state, i.e. political boundaries, borders mean not only geometric line on the Earth surface, but a vertical plane reaching in the Earth's core and above surface in the air space. Thus, in modern times, the national territory is conceived as a cohesive unified space divided from its neighbors by a deliberate clear cut geometric delineation. As already noted, this conception appeared relatively late in the European history and has remained alien to the non-European cultures in the past. Thus, in the ancient Asia, Africa and Americas, borders pointed more or less to the transitory belt or stretch of land, often uninhabited, which could be open for colonization ("virgin lands"; terra nullius). As it will be discussed in the next sections, maritime boundaries constitute a special case of state frontiers. As a state's demarcation of territory and sovereignty, borders also play an important role in the mobility governance regarding movements of population and goods. Besides external borders as dividing lines between states which are internationally recognized and known as state frontiers, there are also internal borders, within a state space, which can be either administrative or possess a constitutional value.

1.5. Legal borders can also be conceived in a wider sense as limits of jurisdiction, which can be either spatial (territorial, maritime, aerial) and/or personal. In the last sense, they constitute an important aspect of the international law, relating to diplomatic privileges and immunities. As such they are based on the principle of extraterritoriality, what means that diplomats (and their families) are exempt from arrests and tax impositions, and that their residences and effects cannot be searched or seized. Diplomats also traditionally enjoy complete freedom of worship.

1.6. Although they physically constitute the margins of the state, borders can be also understood as processes which constitute spatial frameworks for the social constructs within

6 It is interesting to note, that etymology of the German word "Grenze", points out to its Slavic origin ("granica"). Cf. Duden: Herkunftwörterbuch, 3. Aufl., 2001, 302 \& 509.

7 East Germany (German Democratic Republic - DDR), built the Berlin Wall to prevent its citizens from emigrating to the West. The wall was constructed as a system of fortified barriers that were 42 kilometers long. It consisted of massive concrete slabs from 3.7 to 4.6 meters in height, and included armed guards, guard dogs, barbed wire, electric alarms and even mines and trenches. The wall was finally opened in November 1989 and teared down (The World Book Encyclopedia, vol. 2/B, Chicago, 1996, pp. 266-267). 
and beyond the nation-state. In this sense, they represent mechanisms of political communication, a technique of power and filter of mobility's. ${ }^{8}$ As such, they constitute the links between ideologies, foreign policies and the concepts of collective identities, which result into "bordering, ordering and othering in international relations" (S. Reinke de Buitrago, 2017, p. 146). In other words, the formation of national identity is articulated upon spatial extensions and expansions, making political space a core of the nationalist and security rhetoric's. Thus, both as processes and political constructs, borders belong to the realm of symbolic politics, which is articulated around discourses which divide, isolate, and delimit, but also connect and facilitate mobility. Usually, symbolism of the borders is represented through political rituals (i. e. national holidays \& commemorations), but also through symbolic markers, such as flags, anthems, stamps, border stones, fences and inscriptions. Moreover, in the post-modern critical approach, borders appear not only as territorial demarcations, but also as everyday liminal practices of exclusion-inclusion at the meso and micro-levels. In this sense, "bordering" as the process is relevant for the construction of the socio-legal status, life-styles and subcultural values.

1.7. The question of state borders, especially when maritime boundaries are considered, has been for a long time a subject-matter of international law. ${ }^{9}$ But it belongs also to the study of international relations and can be as such, understood primarily in diplomatic, military and strategic terms. ${ }^{10}$ With the collapse of the idea of an universal Christian empire and a central ecclesiastical authority (Holy Roman Empire with a Pope as its spiritual leader) in the early modern Europe, international relations have been conducted by two guidelines: national self-interests (raison d'état) and the balance of power. Later, new patterns of international relations have emerged, including not only the formation of military alliances, but also the idea of a collective security. However, when speaking about international relations, one has to distinguish between the real world and the world of knowledge, i.e. between events in the real world and the thinking about it. In fact, international relations became a discrete subject-matter of study relatively late, being before that included into neighboring disciplines (international law, history, economics, political science). ${ }^{11}$

Although the states are parts of the international community, wherein mutual interdependence, globalization and non-state actors play an increasing role, the state is still the central actor in the community. Hence the most convenient approach to the study of borders is via relations between states. They have been shaped by foreign policy which oscillates between war and peace, conflict and cooperation. Even today, the main target of state's foreign policy is acquisition of strategic, military and economic advantages over other states. In order to

8 Cf. A. Paasi: Boundaries as social processes: Territoriality in the world of flows, Geopolitics, 3, 1968, 1: 69-88 and A. C. Diener \& J. Hagen: Changing modalities of power in the twenty-first century, in: C. Gunay/N. Witjes (eds.): Border politics: Defining spaces of governance and forms of transgressions, Cham, 2017, 15-31, p. 19.

9 For an overview of the concept of state borders in international law, cf. J. Andrassy et alii: Međunarodno pravo, I., Zagreb, 1995., 154.-162. and M. Bothe: Boundaries, Encycl. of Public Intern. Law, vol. 1, p. 443.

10 Cf. C. Brown: Understanding international relations, 2nd ed., Basingstoke/New York, 2001, pp. 1-19; and The World Book Encyclopedia, 10/I, Chicago, 1996, pp. 343-347.

11 In the new discipline of international relations, which developed after the First World War (1914-1918), several meta-theoretical positions emerged under the headings "realism", "idealism", "constructivism" and "institutionalism", which cannot be discussed extensively here. Cf. C. Brown: Understanding international relations, op. cit., pp. 20-67; S. Guzzini: Realism in international relations and international political economy, Routledge, 1998; J. G. Ruggie: Constructing the world polity, Routledge, 1998 \& R. Vukadinović: Osnove teorije međunarodnih odnosa i vanjske politike, Zagreb, 1989. 
achieve this and other aims (including cultural and ideological influence), as for the settlement of disputes, the states have since the ancient times, used diplomacy as a main technique. Diplomacy is essentially an art of negotiation and communication, used to achieve nation's foreign policy aims. ${ }^{12}$ Diplomacy refers also to state's officials that represent their state in relation to other states. Diplomacy is especially important for the establishment of state borders when an armed conflict is over and is to be continued by peaceful means that is agreements and other peace settlements.

As a consequence of the rise of international cooperation and the growing importance of global and regional institutions like the UN and the EU, it was commonly believed that traditional inter-state diplomacy, similar to a chess-like game, has been partially supplemented or even replaced by international cooperation networks and multilateral solutions. ${ }^{13}$ However, recent developments suggest that the preference for narrower engagements and the stress on the protection of national interests are again coming to the fore. The current refugee crisis seems to challenge not only the Schengen agreement, but also the policies relevant to migrations and asylum, posing a threat to the existence of the European Union itself.

1.8. Territorial integrity of the nation-states has been for the long time a core principle of international law, known also the principle of the territorial status quo. It is connected to the postulate of uti possidetis iuris, which was originally applied to the drawing of boundaries in Latin America, then to the decolonized territories in Africa, and lately to the recognition of borders of the newly independent states of the former Yugoslavia and Soviet Union. It means substantially that the borders of the newly formed state correspond to the previous area delimitations unless otherwise agreed. ${ }^{14}$

This principle which aims at the stability and finality of borders is apparently in discord with the principle of self-determination and that of the right to secession. The latter has never been recognized as the valid principles in international law, and the application of the self-determination has been limited for a long time to the former European colonies. As a matter of fact, most of the former British and Spanish colonies in America have gained independence on the basis of self-determination claims. Later, under the impetus of American president Wilson, the idea of self-determination has been extended to the peoples in Europe, belonging to the former Austro-Hungarian, German, and Russian empires. In addition, the fall of the Ottoman Empire, has led to the creation of the new nation-states in Middle-East (Egypt, Syria, Lebanon, Iraq, Jordan \& Saudi Arabia.) Still, African colonies and those in south-east and west Asia, including India as a British crown colony, had to wait the post-1945 developments in or-

12 According to Jules Cambon: "La diplomatie est l'art des négociations... l'ensemble des connaissances et principes nécessaires pour bien conduire les affaires publiques entre des Etats." (cited in Zbornik PFZ, 41/1991, 4-5, p. 465). The term itself covers various meanings: it refers not only to the dealings and the foreign policy skills, but also to an institution (organisational setting, state apparatus, usually Ministry of foreign affairs) and to the research field in politology. Cf:: G.R. Berridge: Diplomacija: Teorija i praksa, Zagreb, FPZ, 2004. (transl.: Diplomacy: Theory and practice, 2nd. ed., Palgrave, 2002).

13 For the history of diplomacy, cf. H. Kissinger: Diplomacija, Zagreb, 2000., originally published as: Diplomacy, Simon \& Schuster, 1994. Also: G. R. Berridge et alii: Diplomatska teorija od Machiavellija do Kissingera, Zagreb, FPZ, 2005. (transl.: Diplomatic theory from Machiavelli to Kissinger, Palgrave, 2001). For the recent developments, cf. R. Haass: A world in disarray: American foreign policy and the crisis of the old order, Penguin Press, 2017.

14 According to the judgment of the International Court of Justice (ICJ), in case of the frontier dispute between Burkina Faso and the Republic of Mali, the purpose of this principle is to prevent "fratricidal struggles provoked by the challenging of frontiers". For this and the general principle of the territorial status quo, cf. for instance, V. Đ. Degan (2002, 205-208) and the sources given in: http://www.oxfordbibliographies.com/view/document/obo-9/80199. 
der to access to independence. As a matter of fact, although recognized by the UN charter, the principle of self-determination had a limited impact in both theory and practice of international relations. ${ }^{15}$ Thus, according to international law, the principle could only exceptionally prevail over the principle of territorial integrity, and in this sense a distinction has been made between internal and external self- determination. While the internal self-determination relates to the collective right of the people of an existing political unit to decide upon constitutional and other rights issues, and is therefore exercised in the realm of an existing sovereign state, external self- determination (containing secession) is prone to controversies. So far, it has been recognized principally in the colonial context or as a product of a mutual consent, usually based upon the constitutional right to secede. ${ }^{16}$ The legal effects of secession are not disputable, if the new state comes into existence and fulfills so-called Montevideo criteria. ${ }^{17}$

1.9. Unlike secession and dissolution of states, there is also an opposite development in international relations; enlargement claims regarding unredeemed space of a nation-state. In difference to the already accomplished territorial acquisitions, these claims have consisted in the grievances by which borders were contested and re-claimed by rivaling states. A claim to an existential border, which is allegedly vital for the full accomplishment of a national project, can be called "irredentism". Originally, deriving from the Italian word for "unredeemed" territories, it constituted both a nationalist political movement and often a building block of official policies, transcribed into constitutional and other announcements.

As in the case of Italy, which will be discussed below in full, a usual way of expressing irredentism was to request adjacent territories by historical, ethnic or strategic arguments. In this, a common way has been the use of the adjective "Greater" as a prefix to the country name. In South-east Europe, irredentist concepts have appeared already within the process of decline of Ottoman and Habsburg empires. But, some of these claims have continued to haunt the international scene until the present-day. One can briefly, in this context, refer to the ideas of Greater Albania, Greater Bulgaria (including Macedonia and parts of Thracia), and to the "Megali Idea" that claims for Greece Northern Epirus in Albania, Cyprus and sometimes even the parts of Thrace and Asia minor given to Turkey by the Treaty of Lausanne. In case of Hungary, irredentist grievances were particularly expressed in the post World War I. period, concerning new borders with Romania, Czechoslovakia and Yugoslavia, established by the Treaty of Trianon in 1920. In Ireland, territorial claims have for a long time concerned Northern Ireland after and before accession to independence. It consists of six counties in the north-eastern part of the island, known also as Ulster area. While the former Irish constitution (1937) provided that the national territory consists of the whole island, Ulster majority

15 Cf. for instance: A. Margalit \& J. Raz: National self-determination, The Journal of Philosophy, 86 (1990), pp. 439-461. UN charter refers to a: "(...) friendly relations among nations based on respect for the principle of equal rights and self-determination of peoples" (The Charter of the United Nations, art. 1/2). Cf. also: J. Crawford (ed.): The rights of peoples, Oxford, Clarendon Pressm 1988.

16 The constitutions of the Soviet Union, Czechoslovakia and Yugoslavia contained the right to self-determination and secession, refering also to the "sovereignty" of the particular republics or nations.

17 They include: a permanent population; a defined territory; the existence of a government, and capacity to enter into relations with other states (Montevideo Convention on the Rights and Duties of States - 1933). Besides Norway, who ended the union with Sweden in 1905, there are several examples of succesful secessions: the case of Senegal (1960), of Singapore (1965), Bangladesh (1971), Baltic states (Latvia, Lithuania \& Estonia - 1991), the Czech Republic and Slovakia (1993) and that of Eritrea (1993). The formation of successor states in the rest of the former Soviet Union and in post- 1991 Yugoslavia, should be considered a consequence of dissolution rather than a secession. 
with the support of the British government, has for a long time opposed the efforts towards unification and cooperation between the two parts of the islands territory. Still, in the eighties, the Republic of Ireland and the Great Britain (which is still officially known under the name: United Kingdom of Great Britain and Northern Ireland), agreed to settle this long-running dispute. In the post-Brexit era, new questions arise concerning future cooperation between these two parts of the island.

1.10. Finally, it should not be overlooked that borders constitute an important criteria for the space delimitation into specific areas, defined by topographical, ethnic, linguistic, economic and political-administrative features. These areas are known as regions and represent intellectual or political constructs, which are designed to facilitate the understanding or to enable control of the given geographical space. Regions may reflect a sense of identity produced by historical and cultural developments, but also exist as artificial institutional arrangements aiming at military, political and economic cooperation. As such they belong to the particular intellectual perspective known as "regionalism", which plays an increasing role in international and domestic politics. So far, in regard to trade and international economic ties, regional institutional arrangements have usually taken form of free-trade zones, customs unions, common markets and economic unions. But, since the end of the World War II, such ties in Europe have evolved from limited free-trade agreements to the European Union, which constitutes a high level of regional integration. As such, EU has proceeded to the re-definition of its border policies and has introduced entirely new system of the internal and external border controls (Schengen agreements).

\section{BORDERS \& TERRITORY. IMPERIAL DESIGNS AND GEOPOLITICS}

2.1. Borders understood as state boundaries, became gradually an important part of the international legal order in the formation of European nation-states. Thus, within the emergence of the modern international law, the conception of state sovereignty has been grafted upon the idea of an undivided power over territory and population, within precisely delimited state borders. In this context, one should mention the overwhelming importance of the Westphalian peace agreements around $1648 .{ }^{18}$ After this settlement, which occurred after the termination of the Thirty Years' War, the international legal order implies the existence of independent sovereign states. Their territories are delimited by state frontiers, which are conceived as linear national borders and not as mere transitory zones. Territorial acquisitions have to be recognized in international law, while the temporary control gained during wartime, can be provisional only. But the international legal order has also allowed both the dominance and territorial expansion of the large states encompassing large portions of the continent. These large entities known as "empires" have dominated the territorial space of Europe from antiquity until their final dissolution. ${ }^{19}$ Empires have a special place in the world's history as they were characterized

18 Cf. entry "Westfalski mir" in: Pravni leksikon, Zagreb, 2007., str. 1786.-1787.

19 Cf. J. Burbank \& F. Cooper: Multiple strategies of imperial statecraft: How empires ruled the world, Le Monde diplomatique, http://mondediplo.com/2012/01/13empire/. 
by: (a) specific way of governance based upon center-periphery relationships, and multi-level domination over large sub-national units; (b) the idea of a continual expansion, usually a colonial one, and: (c) undefined, or changing internal and external borders.

Eastern Europe and the Balkans have been in the past stages of continuous territorial rearrangements and changing state's frontiers. The territorial delimitations before the collapse of great empires have been mostly the product of agreements between great powers, which disputed their "zones of influence" and occasionally agreed on the partition of territories. As it is well known, four empires, Habsburg, German, Russian and Ottoman, after the 1918 did not survive the upheavals caused by the war defeats and the internal dissensions. Their existence has been opposed to the new foundation of state's legitimacy; principle of the nationhood incongruent with the idea of monarchy and church supremacy. With the recognition of national self-determination principle which was brought into prominence by the American president Wilson, in the last years of the World War I, multi-national empires could not survive any longer. Still, in the past, there were notable differences among them in relation to the administrative practices, educational policies and political liberties. Two of these imperial entities had a particular weight in the history of the Balkans and that of the South-east Europe; the Ottoman and the Habsburg one. In addition, for the reflexion on concepts of territory and national identity, the case of France and Italy appear as particularly illuminating.

2.2. Without doubt, Ottoman Empire which grew up from the entity created by the Turkish tribes in Anatolia has been one of the most powerful agglomerate in the world history. ${ }^{20}$ During its age of expansion, at its height it contained most of the southeastern Europe, but was defeated at sea with the Battle of Lepanto in 1571 and on land at the gates of Vienna in 1683. At its height the Ottoman empire included Greece and Bulgaria with parts of the present-day Romania and Ukraine, Serbia, Bosnia and Herzegovina and almost all of Hungary (with a large part of the contemporary Croatia). It also controlled the Middle East and North Africa. The present-day Balkan (South-east European) countries which stayed for a long time under direct or remote Ottoman control, still show the influence of Ottoman heritage in many aspects of public and private life. But this legacy belongs also to the stereotyped foreign images of the Balkans. ${ }^{21}$

After the failed sieges of Vienna, came the decline of the empire's power which progressively lost its former conquests with the defeats in the wars with Habsburg and its allies. Thus, with the peace treaty of Sremski Karlovci (Karlowitz, 1699) came the Austrian reconquest of Hungary and the neighboring territories. On the ruins of the former Ottoman Empire, new identities and imperial projects have emerged. In the European part of the former empire, several liberation-expansionist programs were drawn by the newly liberated Balkan countries. ${ }^{22}$

2.3. The term "Habsburg Monarchy" is a conventional appellation for the territories ruled by the Austrian branch of the House of Habsburg, which originated in Switzerland and after

20 Cf. Encyclopaedia Britannica, https://www.britannica.com/place/Ottoman-Empire.

21 Cf. Todorova (2015, 268-269).

22 After the Balkan wars in 1912 Greece incorporated part of the Aegian Macedonia, but the national programme included also the "megali idea", referring to the restauration of the ancient Byzantine empire. Because of the military setbacks during the campaigns from 1918-1921, Greece had to retreat from the Asia minor and its frontiers with the new Republic of Turkey were settled by the Lausanne peace treaty in 1923. Bulgaria and Serbia have also in the 19th century set up expansionist programmes. That of Greater Bulgaria was supposed to include the whole Macedonia and parts of the eastern Aegean. Serbian expansionist programme has been explicitly formulated by Ilija Garašanin, minister of internal affairs of the principality of Serbia in 1844, in the secret paper ("Načertanije"). 
1279 came to rule in Austria, taking under control the so-called "Habsburg hereditary lands", then progressively the lands of the Bohemian Crown, the Kingdom of Hungary and the territories of Transylvania, Galicia, Bukowina, and for a while, that of Serbia, Italy, and between 1713-1792 also Austrian Netherlands, consisting of today's Belgium and Luxembourg. ${ }^{23}$ As an outcome of the successful military campaigns during Habsburg-Ottoman wars, the empire was able to re-conquer its former possessions in the east and to expand further south. After the dissolution of the Venetian republic and Napoleon's defeat in 1814, Austria also gained possession of Dalmatia, Dubrovnik area and that of several north Italian provinces. In the wake of the Berlin Congress, it acquired also Bosnia and Herzegovina with Sanjak of Novi Pazar. ${ }^{24}$

Habsburg monarchy was a composite state sui generis without a real central government, whose territories enjoyed particular historical rights and privileges, being united only in the person of the monarch. Thus, each province of the empire was governed according to its local constitutions and customs. Still, some attempts at centralization have begun under the rule of Maria Theresia and her son Joseph II and continued in 1849, since the suppression of the internal revolutions of 1848. But the project of the creation of a unitary state ruled from Vienna, with German as the official language, has ultimately failed. After the failure of this project, the famous Austro-Hungarian Compromise was concluded in 1867, by which state territory was divided in two halves, each part having its own parliament and a nominal sovereignty. The common bond was constituted only by a person of the monarch and a joint foreign and military policy.

Although, greater freedoms for the constituent nationalities and minorities existed in the Austro-Hungarian Empire then elsewhere, its unity has been threatened by the dissatisfaction of various ethnic groups and the irredentist claims from the neighboring states. Claims of self-determination traditionally clashed with the idea of historical legality bestowed upon the ruling dynasties, as it was asserted by the Vienna Congress in 1815, after the Napoleon's demise. Therefore, consolidation of its external and internal borders soon became a difficult if not an impossible task.

Even before the Great War in 1914, some plans were set up for the re-designing of the monarchy in the sense of the recognition of more rights to the not-dominant groups, especially south Slavs. ${ }^{25}$ But there was a strong opposition to these projects from the ruling circles in Budapest and Vienna. Finally, the Habsburg monarchy could not any longer resist internal separatist movements, what ultimately led to its dissolution 1918 and to the establishment of the new states on its territory.

2.4. After the collapse of the Russian empire in the revolutionary years 1917-18, its successor state, the Soviet Union, differed from it in many aspects. First of all, the borders of the new state did not correspond to those of the previous Russian empire, as several nations have successfully separated themselves from Russia. Thus, Finland, Poland and three Baltic states:

23 From 1804 until 1867, the monarchy was known as "Austrian Empire" (Kaisertum Österreich) and then it was re-named "Austria-Hungary", in a popular usage also known as "Danubian Monarchy" (Donaumonarchie) and as Double-Monarchy (DoppelMonarchie). The heads of the Austrian branch of the Habsburgs were often elected emperors of the Holy Roman empire until its dissolution in 1806 by Napoleon. Austria-Hungary in: Encyclopedia Britannica (http://www.britannica. com/EBchecked/topic/44386/Austria-Hungary).

25 Cf. Adler (1997) and A. Wandruszka et alii (eds.): Die Donaumonarchie und die südslawische Frage von 1848 bis 1918: Texte des ersten oesterreichisch-jugoslawischen Historikertreffens, Goesing 1976, Wien, 1978. 
Lithuania, Latvia and Estonia, became new borderlands in the western part of the Soviet Union. The new Polish state included the disputed area around the city of Vilnius in Lithuania and contained also a large part of western Ukraine (former Austrian Galicia) with the city of L'viv (known also as: Lavov or Lemberg). ${ }^{26}$ Nevertheless, further secession attempts from Russia (in the Ukraine and in the Caucasus), were successfully obstructed by central government in Moscow and its loyalist supporters. One should also mention the new border line with Romania, which acquired former Russian province of Bessarabia (later becoming Moldavian republic and now independent state of Moldova).

The new Soviet state was radically different from the tsarist Russia, especially by the official culture and ideology. ${ }^{27}$ Instead of a holy alliance between church and throne in the Byzantine tradition, now came millenarian rhetoric of a world revolution. But the legitimacy of such a rhetoric, was fragile and soon was backed by flexible policy changes (the NEP) and other justifications. One of the early legitimizing force and an important shift away from the former Russian imperial policies, has been the proposed solution of the so-called "nationalities question". Thus, Lenin already in 1913 promoted the idea of national self-determination, recognizing the right to secession to Finland and other nations. The particular concern of the Bolsheviks with the nationalities questions, represents without doubts one of the major contributions of Leninism to the classical Marxist ideology, which has been rather reserved or indifferent towards the problem of national rights. ${ }^{28}$ Lenin also proposed a federalist concept of the new state, the USSR, where all the republics were formally, on equal foot. The federal units- republics and autonomous areas- were established according to the principle of nationality and considered as an expression of national sovereignty. ${ }^{29}$ Still, in Stalin's times, Moscow as a center and Russian republic itself became superordinate, reducing non-Russian peripheral republics to the subordinate status. In such a way, Soviet Union appeared as a new disguised form of an empire.

In 1940, Soviet Union proceeded to the annexation of the Baltic States and conquered Polish territories east of the so-called Curzon line. It also seized former Bessarabia from Romania. Besides these territorial acquisitions, victory in the Second World War enabled Soviet Union to occupy a large part of the former East Prussia (Kalingradska oblast) and to seize a part of Czechoslovakia (Carpathian Ukraine). It should be noted that after the war, territorial status quo in Europe has been respected everywhere, except in regard to the Italo-Yugoslav border -modified by the Peace treaty in 1947- and the territorial arrangements in the East. As the rivers Oder-Neiss built the new border line between Germany and Poland, and Italy had to

26 Due to its territorial expansion towards East, Poland before the World War 2 contained a large number of minorities on its eastern borders: Ukrainians, Belorussians and Jews. Danzig (Gdansk) on the Baltic sea, enjoyed the status of a free city, under the protection of the League of Nations.

27 For the Russian imperial policies cf. D. Lieven: Empire, the Russian empire and its rivals from the sixteenth century to the present, London, John Murray, 2000.

28 For Lenin's views, cf. Nationalities policies, Soviet in: Encyclopedia of Russian history, 2004, www.encyclopedia.com/nationalitiespolicies-soviet; R. Zia-Ebrahimi: Empire, nationalities, and the collapse of the Soviet Union, in: Vestnik, 8. 5. 2007: www.sras. org/-nationalities-and-the-collapse-of-the-ussr and in Vukas (1978, 26-30). Within Bolshevik party, Stalin being a Georgian, was considered as an expert in the nationalities questions. One of his earlier works was entitled: Marxism and the national question, Prosveščenie, Nos 3-5, March - May, 1913.

29 While in 1936. the Union was composed of 11 federal republics, in 1941, after the reforms and territorial enlargement in the Baltics, it consisted of 16 units, somewhere containing also sub-units: autonomous republics, regions and districts. 
renounce to its territories on the eastern Adriatic, it was only an exception to the general rule of stability of the post-1919 borders.

As it is well known, after the World War II, the Soviet Union took control of several Eastern European countries, later considered as its satellites, with the exception of Yugoslavia and Albania. But since the late 1980s, the crisis of the Soviet system enabled these countries to dissociate themselves from the Soviet Union and to obtain again a full control of their affairs. In the meantime, the crisis within the USSR led to the collapse of the existing political and legal framework of the Union. Thus, on December 8, 1991, it was announced with the formation of new Commonwealth of Independent States, that the former Soviet Union had ceased to exist. ${ }^{30}$ But, after the breakup of the Soviet Union, regional conflicts have emerged, first in the Chechnya and later in the Caucasus area. Recently, the unrest in Moldova is still a pending issue and the ongoing conflict with independent Ukraine continues to pose a threat to the world's peace.

Table: Important international meetings and agreements concerning state borders in Europe (1878 -1975)

\begin{tabular}{|c|c|c|}
\hline DATE & LOCATION \& TITLE & CONTENTS \\
\hline 3. 3.1878 & San Stefano (now: Yeşilköy) & $\begin{array}{l}\text { Peace treaty between Russia \& Turkey (later invalidated the same year } \\
\text { in Berlin) }\end{array}$ \\
\hline 13. 7.1878 & Berlin Congress & $\begin{array}{l}\text { Berlin Treaty: Recognition of independence of Serbia, Montenegro \& Ro- } \\
\text { mania. Bosnia conferred to Austria. Bulgaria divided into } 2 \text { entities under } \\
\text { Turkish sovereignty }\end{array}$ \\
\hline 3. 3. 1918 & Brest - Litovsk & $\begin{array}{l}\text { Peace treaty between Soviet Russia and the four powers (later invalidated } \\
\text { in 1919) }\end{array}$ \\
\hline 26. 4. 1915 & London-London treaty & $\begin{array}{l}\text { Secret agreement concerning territorial acquisitions in the eastern Adri- } \\
\text { atic between Italy and the Entente }\end{array}$ \\
\hline 28.6. 1919 & Versailles conference & Peace treaty with Germany \\
\hline 10.9.1919 & St. Germain-en-Laye & Peace treaty with Austria \\
\hline 9. 12.1919 & Neuilly & Peace treaty with Bulgaria \\
\hline 6. 6.1920 & Trianon & Peace treaty with Hungary \\
\hline 24. 7.1923 & Lausanne & Peace treaty with Turkey \\
\hline 12. 11.1920 & Rapallo treaty & $\begin{array}{l}\text { Treaty on borders between the Kingdom of Serbs, Croats and Slovenes } \\
\text { and Italy (agreement on Rijeka - 27. 1. 1924) }\end{array}$ \\
\hline 30.9.1938 & München conference & Agreement on the cession of Sudeten to Germany \\
\hline 1945 & San Francisco & UN- foundation \& Charter (26. 6. 1945) \\
\hline 1945 & Potsdam conference & $\begin{array}{l}\text { Temporary delimitation of borders between Germany, Poland \& the So- } \\
\text { viet Union }\end{array}$ \\
\hline $1946-1947$ & Paris conference & Peace treaties with Italy (10. 2. 1947), Bulgaria, Hungary \& Romania \\
\hline 1954 & London conference & $\begin{array}{l}\text { Memorandum of understanding between Italy, the UK, the USA and Yu- } \\
\text { goslavia concerning Trieste }\end{array}$ \\
\hline 10. 11.1975 & Osimo treaty & $\begin{array}{l}\text { Concluded between Yugoslavia and Italy concerning frontiers in the for- } \\
\text { mer Free Territory of Trieste and the delimitation of maritime boundaries }\end{array}$ \\
\hline
\end{tabular}

2.5. For the conceptual model of the nation-building, and the modern ideas concerning sovereignty and consensual democracy, the case of France is of particular interest. Considered, besides England as one of the oldest European nations, France provided a blueprint for

30 For an overview of the recent history of the USSR, $c f$. the article "Russia", in The World Book Encyclopedia, vol. 16, 1996, 547-556. For the post-1991 Siberia and its ethnic relations, $c f$. C. Thubron's observations in his book "In Siberia", Penguin, 2000. 
the state-building in many newly constituted states. Namely, after the 1789 revolution and according to Jacobin designs, the French state has been built around the following principles: centralized (unitary) governance at the expense of local and regional loyalties, uniform and rationalized territorial delimitation (geometrical division of state's space into départements of equal surface), imposition of the unique official language and the state control of the secularized educational system and finally, the principle of "republicanism", i.e. the formal equality of citizens which abolished the former aristocratic privileges and distinctions. ${ }^{31}$ But, France also represents a failed imperial project, as it lost its colonies in North America during 18th century, and as after Napoleon's defeat in 1815, its imperial ambitions were brought to a halt.

It is well known, that the social philosophy and philosophy of political ideas developed by the French authors such as Montesquieu, Voltaire, Rousseau and the Encyclopedians, had an enormous impact not only in Europe, but also overseas in the American continent. As a matter of fact, the intellectual movement known as Enlightenment (Lumières in French; Aufklärung in German), shook the very foundations of the old political order based upon traditional legitimacy of monarchs, church and aristocracy. It contributed to the emergence of revolutionary upheavals first in America (1770), then in France (1789) and elsewhere. ${ }^{32}$ Especially, Rousseau's conception of "popular will" (volonté générale) has been influential in the development of the idea of representative democracy. Moreover, revolutionary and Napoleonic wars also contributed to the rise of national consciousness among various European peoples.

In the French case, one should also take into account its territorial expansion towards east in the 17th and 18th centuries, by which it acquired Lorraine with the bishoprics of Toul, Metz and Verdun, annexed Strasbourg in 1681 and finally joined Alsace to its territory. This development has been completed during the French Revolution when two départements -Bas-Rhin and Haut-Rhin, have been created on the Alsatian soil. Moreover, during the revolutionary and Napoleon's wars, France has extended its borders further north-west, in the way that the entire territory west of the Rhine was incorporated into France. ${ }^{33}$ By the treaty of Luneville (1801), these acquisitions have been recognized as the part of the international law, but after the defeat of Napoleon, the borders of 1792 were restored. As it is well known, the territory of Alsace and of the eastern part of Lorraine, has during the 19th and 20th centuries, twice changed its political affiliation. First, after the Franco-Prussian War of 1870/1871, France was compelled to cede Alsace and the part of Lorraine, including the cities of Strasbourg and Metz, to the new proclaimed German Empire. These new provinces received a special status, and the imperial government sought to introduce modern educational policies and to foster the

31 For the French concept of "nation" cf. in particular: F. Braudel: L'identité de la France, I-III, Paris, Fayard, 1986; J. Godechot: La grande nation, Paris, Aubier, 1983; P. Nora (ed.): Les lieux de memoire: La République; La nation, Paris, Gallimard, 1984-1986; E. Renan: Qu'est-ce qu'une Nation?, in: Discours et conférences, Paris, Calman-Lévy, 1928 (1st published in 1882). There was much of discussion among the historians when and how national consciousness among the French took shape. It seems that in contrast with the German and East European cases, French civic model of nationhood was created and imposed from above, language, habits and symbols of the educated classes being transmitted on the rural world, which remained rather diverse and fragmented. Cf. D. Bell: Recent works on early modern French national identity, The Journal of Modern History, 68 (March 1996), 84-113, pp. 110-111. thought (Montesquieu, Rousseau, Sieyès, Tocqueville, Comte), cf. H. Maier et alii (eds.): Klasici političkog mišljenja, II. Zagreb, 1998. (transl. from: Klassiker des politischen Denkens, Zweiter Band, 1987).

33 Cf. T. Höpel: The French-German borderlands: Borderlands and nation-building in the 19th and 20th centuries, http://ieg.ego. eu/en/threads/crossroads/border-regions/thomas-hoepe. 
development of the Strasbourg University, which soon became the model institution of higher education. Besides German laws and trade regulations were introduced.

Still, some ties with France persisted, although conservative public opinion in the provinces disapproved laicization laws in France as it distrusted the consequences of the Kulturkampf in Germany. It has been observed that "without feeling German themselves, the inhabitants of Alsace and Lorraine nonetheless increasingly accepted the fact that they belonged to the German Empire. They also developed a strong regional identity and campaigned for more autonomy." 34

After the First World War, Alsace and Lorraine were given back to France. Besides, the whole territory west of the river Rhine was occupied by French troops and the Saarland was placed under the administration of the League of Nations. But the French attempts to establish permanently a stronghold west of Rhine, including a partial state of Rhineland, have finally failed. After the Saarland was incorporated into Germany, the borders between France and Germany have been fortified and military secured by the construction of the Maginot line which was intended to protect France from the invasion from the north. On the German side, so-called Siegfried Line (Westwall) has been under construction from 1938. After the World War II., new forms of international cooperation emerged making older geopolitics of borders in Europe obsolete. As a result, existing frontiers between France and Germany became less relevant, opening ways toward inter-state and cross-border exchanges.

2.6. Contrary to France and some other European states which had a long-standing political identity, emergence of Italy as an independent state-nation was a relatively recent phenomenon. After the fall of Roman Empire, the Apennines peninsula has been frequently invaded by foreign powers and divided among independent kingdoms and the republican city states. The popes in Rome with their Papal state, sought also to exercise influence in the political matters and to protect Italy from invasions, but many parts of Italy remained under foreign rule. ${ }^{35}$ In the 19th century, the movement for the liberation and unification emerged known as Risorgimento, and the unification was finally realized under the leading role of the kingdom of Sardinia (Piedmont) and the Savoy dynasty. ${ }^{36}$ The final movement in this process has been achieved with the acquisition of Venice from Austria (1866) and that of Rome, together with the remnants of the former papal state in 1870. Rome became the capital in 1871. But, the economic, social and cultural differences between the more advanced north and the backward south persisted and the national unity lacked a firm basis.

34 T. Höpel: The French-German borderlands, op. cit., p. 6.

35 The works on the Italian history can only marginally be refered to here. $C f$. in particular: G. Procacci: Povijest Talijana, Zagreb, 1996., transl. from: Storia degli Italiani, 1968; and the bibliographical referencies given there. For the development of Italy into a modern state, the following works can be mentioned: N B. M. Clark: Modern Italy:1871-1982, London, 1988; C. Denina: Le rivoluzioni d'Italia, Torino, 1979; H. Hearder \& D. P: Waley: A short history of Italy: From classical times to the present days, Cambridge, CUP, 1963; J. J. Norwich (ed.): The Italians: History, Art and the genius of the people, New York, 1983; L. Salvatorelli \& G. Mira: Storia d'Italia nel periodo fascista, Torino, 1964; A. Schacherl: L'Italia attraverso i secoli, Rijeka, EDIT, 1980; M. Smith: Italy: A modern history, Ann Arbor, 1959; A. J. Whyte: The evolution of modern Italy, Cambridge, 1963 \& V. Zamagni: The economic history of Italy, 1860-1900, Oxford, 1994. Cf. also short summaries in: Atlas Europe, Zagreb, 1977., 359.-367. and in The World Book Encyclopedia, vol. 10, 1996, 496-520, besides Encyclopedia Britannica online.

36 Risorgimento (it.= rising again), represented a political and ideological movement for the unification supported first by the secret societies such as the Carbonari, then by the group of Young Italy led by Giuseppe Mazzini and by other more conservative groups as the Neo-Guelfs and the partisans of the house of Savoy. Cf. I. Montanelli: L'Italia del Risorgimento, Milano, 1972 and "Risorgimento", Encyclopedia Britannica, 2017. 
Almost immediately after the unification, Italy set up an ambitious programme of territorial expansion in Africa and the Mediterranean. After the first war with Ethiopia (1889-1896), it gained Erythrea and acquired Somalia, and after the war with Ottoman Turkey, it incorporated Libya and the Dodecanese islands. It may seem surprising, that such a new nation, with limited resources, being heavily indebted, could commit itself to territorial expansion. But the colonization's and imperial-building programme, had in fact to fulfill several functions: first, to alleviate the problem of over-population (which prompted massive emigration overseas), second, to provide resources (esp. coal, petrol, iron ore) which were scarce and third, to win the confidence and wider support for the central government. Italian foreign policy before the World War I. reflected internal political divisions and irredentist claims hesitating in choice of alliances. It entered first into relations with Austria and Germany forming the Triple Alliance in 1882, and stayed out of fighting at the beginning of the war.

After signing the secret agreement with the Allies in 1915 in London, Italy entered the war on the side of France, Great Britain and Russia, and fought for two years along the Soča (Isonzo) river with little success suffering enormous casualties. Finally, with support from its western allies, Italy achieved a victory near the town of Vittorio Veneto, what was later celebrated as a great military achievement. After the Austria-Hungary signed an armistice on November 3, 1918, Italian forces quickly occupied Trento and South Tirol, later awarded to Italy by the peace treaty with Austria in St. Germain in 1919. In the same time, Italian military entered into Trieste, Istria, southern parts of Crain, Quarnaro islands, neighborhood of Rijeka and attempted to disembark into Dalmatia. Still, as American president Wilson did not recognize the London treaty and suggested more equitable border delimitations, a period of stalemate occurred with several diplomatic initiatives aiming at the agreement on the frontiers in the Adriatic. In particular, for several years, the case of the city of Rijeka (Fiume) was a bone of contention and a matter of concern for the peace, until the final agreement was reached in 1924, with the city annexation to Italy. ${ }^{37}$ The other borders with the Kingdom of Serbs, Croats and Slovenes were settled before by the Rapallo treaty in 1920.

In spite of the post-war territorial acquisitions, the new border settlements were not considered as entirely satisfactory by some circles ("lame victory"), especially in view of the immense war effort. Partly for this reason and mainly because of the economic crisis, an internal unrest has led to the establishment of the dictatorship by the fascists led by Benito Mussolini (called Il Duce). As they took power in October 1922, their way of governance combining state intervention in economy, totalitarian control of the public life and a use of terror, became a model for similar movements elsewhere. As it is well known, since the rise of fascism, Italy was almost continuously committed to the military conquests and wars. Thus, it conquered Ethiopia in 1936, seized Albania in 1939 and started a military campaign in Greece in 1940. It also entered the war in Europe in 1940 on the side of Germany, being already linked to it from 1937, by the Rome-Berlin Axis. But, series of defeats by the Italian army and the victorious Allies invasion

37 As Rijeka has not been promised to Italy by the London treaty, it was suggested to include it into the newly constituted free city state. In September 1919, Italian poet Gabrielle D’Annunzio with his followers occupied Rijeka and proclaimed it as "Regency of Carnaro". It was meant to function temporarily as an independent unit, until the final annexation to Italy. D'Annunzio ruled in a theatrical fashion displaying nationalist rhetorics and emotional appeals. He produced an original constitutional document with corporativist elements. Cf. Bartulović (2004); Lj. Toševa-Karpowicz: D’Annunzio u Rijeci: Mitovi, politika i uloga masonerije, Rijeka, 2000.; and F. Čulinović: Riječka država: Od Londonskog pakta i Danuncijade do Rapalla i aneksije Italiji, Zagreb, 1953. Also: R. De Felice: D’Annunzio e l’impresa fiumana, in: D’Annunzio politico (1918-1938), Roma/Bari, 1978. 
of Sicily on July 10, 1943, followed by their advances in southern Italy, prompted Mussolini's fall from power and the proclamation of surrender (act of capitulation, otherwise called "armistice", issued on September 3rd, 1943). These events contributed to the rise of the anti-fascist resistance movement (the partisans) and the growing influence of the Communist and Socialist parties.

In the post-war years, Italy has become a republic and had to sign a peace treaty in Paris on February 10, 1947, by which, it lost its former possessions in Africa and the Dodecanese islands. It had also to recognize new border with Yugoslavia, which was drawn upon the French proposal, more favorable to Yugoslavia than the British and American frontier suggestions, but less so than the Soviet version. ${ }^{38}$ The city of Trieste with the neighborhood area, including north of the Istrian peninsula, was foreseen as the separate entity (Free Territory of Trieste) under joint administration of the US, Great Britain and Yugoslavia. Still, the agreement concerning Trieste has not been implemented and the future of the city and its surroundings has been decided only by subsequent arrangements (1954 \& 1975).

2.7. One of the particular and long-standing features of the Italian political culture has been the irredentism as an ideological movement which exercised a considerable influence on the foreign policy of the Italian state having also a great impact on the public life in general. "Irredenta" concerned mostly eastern Adriatic, but occasionally also other areas in the Mediterranean and elsewhere. ${ }^{39}$

Although the term "terre irredente" appeared only in 1877, when it was introduced into political vocabulary by Matteo Renato Imbriani, its meanings could be found already in the earlier projects of the Italian unification, although it should not be confused with the Risor-gimento and with the later imperial and fascist policies. As a matter of fact, one could speak about two meanings of the term; first, a "benign" one, which consisted into claims to return to Italy only the areas, where the Italian-speaking population had a majority and the second, belonging to the more aggressive and exclusive nationalist discourse, which denied the rights of other groups on the territories claimed to Italy. ${ }^{40}$

It could be easily observed that irredentist projects and policies were conducted on four levels; first, through diplomacy and foreign policy; second, with military campaigns and the territorial conquest; third, through propaganda, media and associations networks, and fourth, with the use of political violence, including clandestine and terrorist activities. Regarding media and the propaganda networks, already in last decennies of the 19th century, several associations came to the forefront of public life; the movement Pro Patria in 1885, Dante Alighieri society founded in 1889 and in 1891 the Lega Nazionale association. Though, officially opposed

38 Cf. V. Dedijer: Pariska konferencija, Zagreb/Beograd, 1948. and A. Mitrović: Jugoslavija na konferenciji mira u Parizu, Beograd, 1969. Cf. also D. Rudolf: Povijesni tijek uspostavljanja državne granice između Republike Hrvatske i Talijanske Republike, Problemi sjevernog Jadrana, 12 (2013), str. 9.-25.

39 Irredentist claims included besides eastern Adriatic, Trentino and South Tirol, French controlled territories of the county of Nice, Savoy and Corsica, British Malta and the Italian speaking parts of Switzerland. It is interesting to note, that the former Genoan island of Corsica - a birthplace of Napoleon - has led one of the Europe's first wars for self-determination in the 18th century (Pasquale Paoli's uprising in 1768). Still, although close to Italians, by linguistic affinities, the Corsicans have been much more oriented towards regional autonomy and independence- backed even today by political violence and terrorism - than towards unification with Italy. Cf. for instance, the recent French newspaper report: Regain de violence nationaliste en Corse: La justice craint l'essor d'une nouvelle radicalisation armée, affranchie des groupes historiques, Le Monde, 7/8, 5, $2017,11$. 
to the irredentist claims of these movements, several Italian governments secretly helped and encouraged their activities. ${ }^{41}$ Political violence, although rare in the beginnings of the irredentist movements and before the Great War, has later spread out with the rising anti-Slavic and xenophobic feelings, especially after the coming to power of fascism. ${ }^{42}$

From the periodization point of view, it could be observed that Italian irredentism evolved, generally speaking, through four main stages; first, running from the Risorgimento until the 1915 agreement and the entry into the war on the side of Entente, second, in the period of the military interventions and diplomatic activities from 1915 until 1920; third, in the fascist period, and fourth, in the context of the international relations following post-1943 capitulation, peace settlements and the relationships with the neighboring Yugoslav state until the Osimo treaty. During the first irredentist period, Italian political and intellectual leaders have not yet formulated a clear and unambiguous project of the territorial expansion in the eastern Adriatic. There were even voices which regarded with sympathy South Slav aspirations, considering them as the natural allies in the struggle against Austria and the Pangermanism, seen as a main obstacle to the Italian unification. In particular Giuseppe Mazzini - leader of the Giovine Italia - supported South Slav aspirations, being undecided about northern border line, suggesting at times Isonzo river-mouth and later, Trieste, Kras and Istria as the future borderlands of the Italian state. Camillo Cavour, who used for the first time the name of "Julian March" (Venezia Giulia), put forward the idea of "natural borders" of Italy, what soon became the cornerstone of the irredentist argumentation. ${ }^{43}$ Irredentist voices became stronger after the war with Austria in 1866 and the following decennies. There was also among Italians in Austria-who were until that time mostly loyal to the Austrian state-a growing feeling of anxiety regarding their future, especially considering South Slav national awakening, what was reflected in the political and cultural conflicts in Istria and Dalmatia.

In the second phase of irredentism, the irredentist aspirations have won international support thanks to the Italian diplomacy which contributed to the signature of the London Pact in 1915. Still, the mere fact that Italy was on the victorious side at the war end, did not immediately and entirely satisfy previous territorial pretensions. They were somehow hold back by president Wilson's interventions regarding Dalmatia and his proposals for the ethnic boundary in Istria (so-called Wilson line). Also the situation in Rijeka was a confusing one, Italy having at first agreed on the establishment of the free city state, to accept later the possibility of an annexation.

The third period was characterized by the rise of fascism and the beginning of repressive and assimilationist policies of the central and local power centers which included in that time, not only official state's agencies, but also para-military groups belonging to the fascist move-

41 On the Austro-Hungarian territory, several similar movements were also founded: Giovane Trieste in 1897, Trento-Trieste in 1903, and Giovane Fiume, 1913.

42 One of the early acts of the political violence produced by the irredentist claims, was the assassination attempt against the Emperor Francis Joseph in Trieste 1882, where one of the members of the plot, Guiglielmo Oberdan was caught and later executed. The burning down of the Slovene cultural centre in Trieste 1920, represents a spectacular act of the irredentist violence and xenophobia at the outset of fascism.

43 Italian "natural border" conceptions usually refered to the Julian Alps, Snežnik (Monte Nevoso) and the Učka (Monte Maggiore) mountains. In other versions, they were drawn further south, alongside the mountains of Velebit and Dinara, including Dalmatian coast. The term Venezia Giulia, become equivalent designation for Istria,Trieste and the Gorizian area extending to the foot of Julian Alps, while Venezia Tridentina indicated Trento and South Tirol. 
ment. Special attacks were directed against Croatian and Slovene cultural and educational institutions, such as schools, libraries, cultural societies and against individuals among the teachers and the clergy. Following totalitarian indoctrination of the youth, only school teachers loyal to the new regime were employed, together with the compulsory participation of the children in the fascist youth organizations such as Balila, GIL, ONAIR etc. There was a ban on the use of Croatian and Slovene language in church and in the public. A great number of family names were changed by force from the Slavic version to an Italian form. ${ }^{44}$ This situation has worsened with the Italian entry into war on the side of Germany and the subsequent occupation and the attempts at the annexation of the former Yugoslav territories.

In the fourth and what could be called "final" period of the irredentist evolution, it has formally disappeared from the official policies in order to survive among exile groups and in extremist discourse. Still, after 1947. Italian state was particularly concerned with the alleviation of the effects of the Parisian peace treaty, concerning precisely status of the zone of Trieste. When the final agreement was reached on this question first in 1964 and definitely in Osimo, 1975, the relations between two states -Italy and Yugoslavia, could take a new turn and improve substantially. One should nevertheless also point out to the ethnic composition effects of the state border changes following peace treaty in 1947, as a large part of the Italianspeaking citizens- together with some Croats- have left the Yugoslav state territory, benefiting from the special 1947, peace treaty clauses. ${ }^{45}$

Finally, it could be said, that in the past, Italy had neither resources nor a reasonable economic interest to expand and control large territories with ethnically diverse populations, who have already reached higher degree of cultural and political maturity, and shared another national consciousness. If the Italian colonial administration in Africa and elsewhere was to some extent successful, the modern conception of international relations did not allow for imperial and assimilationist tendencies in Europe. Thus, that the Italian irredentist project, especially in its fascist version, was in itself unrealistic. As a concluding remark, it could be said that the main reason for its failure, was its irrational and self-defeating nature.

\section{MARITIME BOUNDARIES \& INTERNATIONAL LAW}

3.1. Maritime space differs substantively from land in regard to the ways of control, but especially regarding the allocation of legal rights. It has been usually observed, that contrary to land, water is not habitable, or only in the limited sense, exceptions being house-boats, ships,

44 There are numerous publications concerning Italian foreign policy and irredentism before 1920 and after the rise of fascism. One can point out in particular to: D. Šepić: Italija, saveznici i jugoslavensko pitanje, 1914.-1918., Zagreb, 1970. and his article in the special issue of the review Časopis za suvremenu povijest (Šepić, 1975., str. 5.-32.). Cf. also several works in the collection entitled: Talijanska uprava na hrvatskom prostoru i egzodus Hrvata (1918.-1943.): Zbornik radova s Međunarodnog znanstvenog skupa, 1997., Zagreb, 2001., in particular those by Strčić (2001., str. 19.-60.); M. Kacin-Wohinz: Jugoslavensko-talijanski odnosi i slovensko-hrvatska manjina u Italiji između dvaju ratova, str. 71.-96. and I. Pederin: Italia irredenta i Dalmacija do 1919., str. 303.-348. Cf. also: E. Radetić: Istra pod Italijom 1918-1943, Zagreb, 1944. \& Rijeka, 1992.

45 This post-war emigration (conventionally called "exodus" by Italian authors and media propagandists), amounts to 146.000 persons, 116.000 among them being ethnic Italians, while the 30.000 could be considered as Croats, according to data provided by Vladimir Žerjavić. Cf. V. Žerjavić: Doseljavanja i iseljavanja s područja Istre, Rijeke i Zadra u razdoblju 1910-1971, Društvena istraživanja, 2 (1993), 6-7, 631.-656. F. Dota, Zaraćeno poraće. Konfliktni i konkurentski narativi o stradanju i iseljavanju Talijana Istre, Zagreb, Srednja Europa, 2010. 
submarines, and floating oil platforms (rigs). Consequently, rules and institutions belonging to the law of the sea are not the same as those which govern sovereign rights on the land. ${ }^{46}$ In the development of international law, maritime space outside the coastal waters has been conceived as res communis available to all, even if specific rights and privileges were granted to the coastal and other states. Recent changes in the international law of the sea have extended these specific state's rights especially in relation to the customs controls. Furthermore, scientific exploration and commercial exploitation of natural resources were made widely available to all states, even outside coastal zones. Still, so-called "land-locked" and geographically disadvantaged states do not enjoy full access to the maritime space and its resources as the coastal states. ${ }^{47}$

In the past, attempts to control maritime space remained limited to the coastal areas, where sometimes, with the state's sponsorship, piracy has been practiced as a way of life, what is even today a considerable risk for the sea traffic in Africa and south-east Asia. ${ }^{48}$ Maritime explorers and peoples who strived to conquer the maritime space, like the Spaniards, Genoans, Venitians, Portuguese, English and Dutch, competed over maritime space and occasionally sought to reach some agreement in the matter as in Spanish-Portuguese interest spheres agreement about maritime and overseas possessions in 1494. Only after the 17th century, mostly under the impetus of the "open sea" (mare liberum) doctrine, prompted by the distinguished Dutch legal scholar Grotius - founding father of the science of modern international law-maritime space has become a free zone, mare liberum and res communis, with the exception of the territorial (coastal) waters.

But, especially after the years following World War II, many states sought to increase their control over maritime areas, what prompted efforts to codify and innovate international law of the sea. So, under the auspices of the United Nations, several conferences were held on these questions. The most successful was the Third United Nations Conference on the Law of the Sea, which took place in 1982. It produced the United Nations Convention on the Law of the Sea (further referred as: UNCLOS), which was opened for signature on Dec. 10, 1982 in Montego Bay (Jamaica), and went into effect in 1994, when sixty required ratifications were obtained. ${ }^{49}$

3.2. According to these developments in the law of the sea, the following maritime spaces can be distinguished: internal waters, territorial sea, archipelago waters, contiguous zone, exclusive economic zone and the continental shelf. In principle, coastal state possesses full sovereignty on the first three zones, i.e. in the internal waters, territorial sea and in the archi-

46 On this distinction, cf. J. Andrassy et ali: Međunarodno pravo, I., Zagreb, 1995., 172.-222. and L. Brilmayer/N. Klein: Land and sea: Two sovereignty regimes in search of a common denominator, Intern. law and politics, vol. 33 (2001), 703-769. Similarly, the outer space, including the moon and celestial bodies, is not subject to national appropriation by claims of sovereignty. For the Adriatic sea as a dividing and unifying cultural space, $c f$. E. Cocco: I territori liquidi: Forme et confini di un immaginario adriatico, in: E. Cocco \& E. Minardo (2007, 11-26).

47 As it is well known, "land-locked" states in Europe are: Austria, Belarus, Czech Republic, Hungary, Liechtenstein, Luxem-bourg, Macedonia, Moldova, San Marino, Serbia and Switzerland. On these concepts $c f$. L. Caflisch: Što je država u nepovoljnom geografskom položaju, Zbornik PFZ, 35 (1985) 5-6, str. 599.-612.

48 For piracy in the Adriatic during 16th and 17th centuries, cf. C. W. Bracewell: The Uskoks of Senj: Piracy, banditry, and holy war in the sixteenth-century Adriatic, Ithaca, 1992.

49 Cf. L. Brilmayer \& N. Klein: Land and sea, op. cit., esp. pp. 716-746; V. Ibler: Teze za diskusiju. Novo međunarodno pravo mora, Pravo i društvo, III., 1982.-1983., Zagreb, JAZU, 1984., 1.-13. and B. Vukas: The impact of the Third United Nations Conference on the Law of the Sea on Customary Law, in: C. L. Rozakis/C.A. Stephanou (eds.): The new law of the sea, 1983. 
pelagos. The other zones cannot be considered as parts of the state's territory submitted to its sovereignty, but the coastal state may exercise some powers on them.

Among the afore-mentioned maritime zones, some were entirely new legal institutes, accepted as innovations by The Third United Nations Conference on the Law of the Sea in 1982 and inserted into UNCLOS Convention. Besides introduction of archipelago waters and of exclusive economic zone, further innovation has been new conception of the continental shelf which was enlarged to the distance of 200 maritime miles from the starting measurement line. The "transit passage" was also the new institute replacing existing right to the "innocent passage" in the straits. In the UNCLOS's text in 1982, also appeared reference to the deep seabed known as "area". It was defined in the Article 1 of UNCLOS as "the sea-bed and ocean floor and subsoil thereof, beyond the limits of national jurisdiction". The UNCLOS Convention has also stressed - for the first time in the history of international law - the need for the protection of maritime environment.

Table: Maritime zones according to UNCLOS

\begin{tabular}{|l|l|l|}
\hline MARITIME ZONES & EXTENSION & LEGAL STATUS (REGIME) \\
\hline Inner waters & $\begin{array}{l}\text { Variable = extension of a land } \\
\text { territory }\end{array}$ & Full sovereignty \\
\hline Territorial sea & 12 nautical miles & Sovereignty with exception of "transit passage" \\
\hline Contigous zone & 24 nautical miles & $\begin{array}{l}\text { No sovereign rights. Jurisdiction concerning } \\
\text { customs \& other regulations }\end{array}$ \\
\hline Exclusive economic zone (EEZ) & $\begin{array}{l}200 \text { nautical miles from the } \\
\text { demarcation of territorial sea }\end{array}$ & Multiple use of natural resources \\
\hline $\begin{array}{l}\text { Continental shelf = prologation } \\
\text { of the land to the outer edge } \\
\text { of the continental margin }\end{array}$ & Max. 350 nautical miles & $\begin{array}{l}\text { Sovereign rights concerning the seabed and } \\
\text { subsoil of the submarine areas }\end{array}$ \\
\hline Open sea (High seas) & - & Freedom of navigation \& exploration \\
\hline $\begin{array}{l}\text { Archipelago waters = maritime } \\
\text { space between islands }\end{array}$ & Special case & Sovereignty with exception of "transit passage" \\
\hline $\begin{array}{l}\text { Area }=\text { seabed, ocean floor \& } \\
\text { subsoil beyond the limits of } \\
\text { nat. jurisdiction }\end{array}$ & Special case & $\begin{array}{l}\text { Reciprocating states regime = agreements } \\
\text { concerning deep seabed mining areas }\end{array}$ \\
\hline
\end{tabular}

3.3. The Adriatic Sea belongs to the maritime space of semi-enclosed seas, according to the terminology adopted at the UNCLOS Conference. Its access from the Mediterranean is only possible through the Otranto straits, where is the junction of the Albanian and Italian territorial waters. From the geographical and historical point of view, eastern Adriatic could be divided into three zones: north (Istria, coast until Velebit), central part (from Velebit to Kotor/Cattaro) and the southern part (contemporary Montenegro and Albania). ${ }^{50}$ Until the Napoleon's conquest, entire or a large part of the maritime space in the Adriatic was controlled by Venice, what included major part of islands and a large part of the coast in Istria and Dalmatia, with the exception of the territories belonging to the Habsburg, Ottoman and Dubrovnik possessions. It should be noted, that the Venetian claims to the exclusive rights in the Adriatic (dominium maris Adriatici) - later revived in the Italian "irredenta" projects- were nevertheless permanently contested first, by the early Croatian rulers, then by the Ottomans 
and the Habsburg, whose emperor Charles the VI proclaimed in 1717 Adriatic, a free maritime zone (Katičić, 1953, 95). ${ }^{51}$ Even before that, the uskoks in the Croatian city of Senj have for a long time successfully disturbed Venetian trade and navigation, engaging into acts of piracy.

Although, Dubrovnik republic, under the protection of the Ottomans, was seldom directly involved into territorial disputes, it also remained a constant rival of Venice on the sea.

It should be stressed, that for Croatia, although it has not been a maritime power in the past, the Adriatic Sea has been during history a privileged maritime environment providing essential means of living for its coastal population. As a matter of fact, the Croats have during centuries used the sea for fishing, navigation and the ship building purposes. Even when Croatia belonged to the territories of other composed states (partly to Austria and Venice, then to Austro-Hungary and Yugoslavia); it was the Croats, who carried out the whole or a large part of the maritime activities belonging to these states. ${ }^{52}$

Since the dissolution of Yugoslavia, the maritime space of eastern Adriatic includes besides Croatia, also water areas belonging to other new states such as Slovenia, Bosnia-Herzegovina and Montenegro, although on a much more smaller scale. Italian maritime space, which enters into contact with the Croatian territorial sea in the Gulf of Trieste, is delimited under the provisions of the Treaty of Osimo, concluded on 10 November 1975. Actually, Croatian maritime space includes almost all the islands of the eastern Adriatic, making Croatia the second largest archipelago state in the Mediterranean. Out of 1.244 large and small islands, there are only 50 inhabited. The islands have been proclaimed by the Constitution (Art. 52/1) as natural assets of interest to the Republic and have been also considered as a special area of development policy. ${ }^{53}$

After the accession to independence in 1991, Croatia has adopted all conventions and boundary arrangements relating to the law of the sea of the predecessor state- the SFR of Yugoslavia. ${ }^{54}$ In addition, new national rules of the law of the sea were included in the Maritime Code adopted by the Croatian Sabor on 2nd February 1994. The LOS Convention after its entry into force in 1994 has also by the succession principle been extended to Croatia as one of the successor states of the former SFRY, who was one of its previous signatures.

As it is well known, there have been disagreements concerning terrestrial and maritime boundaries between Croatia and Slovenia. Particular matter of dispute has been the maritime boundary in the Bay of Piran (Savudria), which as it was claimed, could offer an access to

51 The ceremony called "marriage to the sea" was performed occasionally by the Venetian authorities, as a symbolic act attesting the exclusive rights on the sea.

52 Cf. for an historical overview of the Croatian presence in the eastern Adriatic, cf. Vukas (1996.) and Rudolf (1996.). It could be added that so far, many Croatian authors have extensively studied law of the sea. One can cite among them: Andrassy (Epikontinentalni pojas, 1951.), Ibler (Sloboda mora, 1965.), Katičić (1953.), Rudolf (Međunarodno pravo mora, 1985.) and Zoričić (Teritorijalno more, 1953.).

53 Data on the geographic position and demographic conditions of the islands, besides other sources, can be found in the Report on the implementation of the Law on Islands, published in 2009 by the Zagreb Ministry of sea, transport and infrastructure (Ministarstvo mora, prometa i infrastrukture: Izvješće o učincima provedbe Zakona o otocima, Zagreb, 2009., 3). the navigation, particularly regarding foreign vessels and the rule of "innocent passage". These areas included inner and territorial waters alongside of Brijuni (Brioni) islands, Goli otok, and the islands of Vis and Lastovo. Cf. the map entitled: Granice teritorijalnog mora SFR Jugoslavije i R. Italije i zabranjena područja uz obalu SFRJ, joined as an appendix to the unpublished doctoral dissertation by Tomislav R. Đorđević: Jadransko more u svetlosti savremenog prava mora i savremenih međunarodnih odnosa, Beograd, Pravni fakultet, 1984. 
the open sea. The dispute was submitted to an independent arbitration board, which recently reached a decision, awarding to Slovenia a large part of Piran's bay. As it is usually admitted in this kind of settlement, such a decision could be guided not only by the norms of the international customary law, but also by equity principle. However, conclusions of this arbitration board seemed unacceptable to Croatia, due to the alleged undue influences on the members of the board. Therefore, Croatian maritime and territorial boundaries with other former Yugoslav republic remain unsettled.

\section{BORDERS AND IDENTITY. ETHNICITY \& NATION-BUILDING. NAMES, SYMBOLS \& RITUALS IN BORDER POLITICS}

4.1. Group borders appear as essential components in the relationship between state, nation and territory, or to put it otherwise, as the basic element of the spatial construction of group identities. Basically, the concept of identity ("we") is coupled with that of alterity ("other"). ${ }^{55}$ With the rise of modern European nation-states based upon the principle of a territorial sovereignty, borders have become important force into shaping national unity and identity. But, group borders were often less the product of the spontaneous processes, than a result of the conscious effort by the elites for creating collective identities with the support of political ideologies. One can even speak in this sense of the "political engineering" as an essence of a nation-building. In this way, elites sought to organize and control space by creating standard language at the expenses of local dialects, setting up local administration, and building up schools and the educational system. As such, borders constituted important cornerstones in the state's policies of institutional integration and cultural assimilation.

In Europe, as one of the smaller continents, where spatial and climatic conditions allow for a larger population density, there have during history co-existed various human groups having separate or differentiated identities. ${ }^{56}$ Outside Europe, the term "tribe" has been widely used in reference to the ethnic composition of Africa, where even today, tribal loyalties remain vital component of the nation's culture and politics. One can also observe so-called "ethnic mosaics" i.e. the areas with the mixed population, as in the Near East (Turkey, Syria, Lebanon, Iraq) and in the Caucasus area. Ethnic mixtures have for the long time coexisted in Central Asia, on the borders of China \& India, and in South-east Asia. In North and Central America, since the Spanish and British conquest, the larger groups of indigenous population have co-existed

55 The concept of identity has been recently widely used in social research, particularly in the context of cultural, ethnic and gender studies. According to Manuel Castells, it is possible to distinguish three kinds of identities: legitimizing, built by an elite for rationalizing its view; resistance identities usually beloging to the marginalized groups and the third one: project identity, which can be used for various purposes in order to dynamize existing state of affairs. Cf. M. Castells \& M. Ince: Conversations with Manual Castells, Cambridge, Polity Press, 2003, 69-70. As we have argued in one of our previous works, modern political ideologies are far more fragile constructs than relatively stable traditional symbols and identities ("Culture change and symbolic legitimation: Functions and traditional meanings of symbols in the transformation of Yugoslav ideology", unpublished doctoral dissertation, University of Bielefeld, 1985).

56 Cf. F. Fernández-Armesto (ed.): The Times: Narodi Europe, Zagreb, 1997. (The TIMES Guide to the peoples of Europe, London, Times Books, 1994); R. Simeon: Enciklopedijski rječnik lingvističkih naziva, I.-II., Zagreb, MH, 1969. and Atlas jezika: Podrijetlo i razvitak jezika u svijetu, dop. izd., Varaždin, 2004. (transl. from: The atlas of languages, rev. ed., London, Quarto Publ.). For the controversial issues connected with Croatian identity, cf. the collection "Hrvatski identitet: Zbornik ", Zagreb, MH, 2011. 
together with the descendants of the European settlers. In the world's smaller continent- Australia, "aborigines" are well- known remnants of the primeval population.

These groups can be considered upon various criteria; according to their numerical importance, one can distinguish between majority and minority groups within the same territory. Other criteria include language, religion, way of life (sedentary or nomadic), political allegiance and a sense of collective destiny. It is important to note, that while state borders change through history, some boundaries may remain fixed either as natural barriers or as the parts of the collective imaginary. As an example of this, one can mention the fourth century partition between the Eastern and Western Roman empire on the river Drina (stretched from the Adriatic coast to the confluence of the Sava and the Danube), that today delimitates Bosnia and Croatia from Serbia and Montenegro.

4.2. If we now turn to the basic concepts in the reflexion on the processes of the nation-building, then one has to distinguish between ethnic groups and minorities as small-scale communities and the larger groups supported by the institutional framework of the official culture and the political consciousness. In this sense, ethnicity can be seen as a quasi-natural phenomenon, while the "nation" is rather an elite construct. ${ }^{57}$ Thus, while the members of an ethnic group usually share the same way of life, use identical or similar language or belong to the one religious observance, the sense of nationhood transcends these limits. As seen in the French case, traditional village life constituted a cultural isolate where peasants used the "patois" as mother tongue, and the standard language was learned in the schools and during the military service. Besides this distinction between ethnicity as the spontaneous or a "natural" phenomenon and the national consciousness seen as a cultural and political construct imposed from above, one has also take in account the modalities of way of life and the material culture. They have been an object of a study by anthropologists and ethnographers, who focused on traditional rural communities. Finally, there is also the question of local and regional identities which are usually situated in-between ethnic and larger loyalties.

Briefly, one can distinguish between the following four levels in the analysis of the phenomena of ethnicity and nationalism, starting from bellows the scale:

- ethnographic and socio-geographic aspects;

- studies focused on ethnic identifications and distance;

- research on national culture and politics, which includes history of political parties and movements;

- regional studies including sub-regional identifications.

On the first ethnographic level, social research is concerned mostly with the phenomena of customs, family, kinship, material culture and folklore. ${ }^{58}$ The most valuable appear the area

57 Studies on ethnicity and nationalism are too numerous to be cited here in extenso. Cf. B. Anderson: Imagined communities: Reflections on the origin and spread of nationalism, London, 1983; W. Connor: When is a nation?, Ethnic and racial studies, vol. 13, 1990, 1:92-103; and his book: Ethnonationalism: The quest of understanding, Princeton, 1994; T. H. Eriksen: Ethnicity and nationalism, 2nd ed., London, 2002; V. Katunarić: Sporna zajednica: Novije teorije o naciji i nacionalizmu, Zagreb, 2003; H. Seton-Watson: Nations and states: An enquiry into the origins of nations and the problem of nationalism, Boulder, Colo, 1977; A. D. Smith: Introduction: Ethnicity and nationalism, Intern. journal of comp. sociology, 33, 1992, 1-2, 1-4 and his books: The ethnic origins of nations, Oxford/New York, 1986 and: Chosen peoples: Sacred sources of national identity, Oxford, 2004.

58 Cf. for instance: H. Bausinger /Bauzinger/: Etnologija: od proučavanja starine do kulturologije, Beograd, 2002 /orig. published as: Volkskunde: Von der Altertumforschung zur Kulturanalyse, Tübingen, 1999/. 
studies, which show similarities and differences between small rural and urban communities. While traditional European ethnography dealt with this matter within national space, the social and cultural anthropology developed in the Anglo-American realm enlarged its focus in the comparativist perspective. "Culture" appears as the central concept in this research. ${ }^{59}$ Some recent studies show a revival of interest into the somehow neglected local folklore traditions in connection with cultural industries and tourism.

The concept of the ethnic group as well as that of the phenomena of "ethnicity" and "nation-building" is a complex and largely controversial issue. In this connection, it is possible to point out to two polar categories proposed by Tönnies in 1887; the concepts of "Gemeinschaft" and "Gesellschaft". While the first one refers to a village community, where the behavior is traditional, spontaneous \& non-reflective, the Gesellschaft type of group is more open, rational and reflective. ${ }^{60}$ Thus, an ethnic group can be understood as a community possessing a common sense of belonging with or without territorial bounds, but showing strong linguistic and cultural homogeneity.

The concept of "nation" is commonly associated to the state and politics in general. In difference to the ethnic groups which are primal and natural communities, nations appear as constructs build through history by elites, in particular by intelligentsia, and linked to the institutional framework of the state and its policies fostering symbolic unity of a territorially bound community ${ }^{61}$ In this process of nation-building, there were also present processes of modernization which compounded industrialization, mass communication and secularization undermining traditional bounds. Since then, church and monarchy lost their importance in the legitimization of the state, which stayed upon the idea of a nation.

4.3. In discussing highly complex phenomenon of "ethnicity" and the ethno-national boundaries, one could point out to the groups of transitional or transnational nature. They constitute liminal cases of identifications in the spatial and time perspective within unstable and changing boundaries. The key concepts in this context appear as reference to territoriality, exclusivity, communication of cultural differences, and finally, insertion into power relations and symbolic politics. In this sense, ethnicity could be seen as relation and situational phenomena that can be re-interpreted and instrumentalized according to the historical situation (Eriksen, 2002, 57-58).

Thus, there are hybrids, amorphous, dispersed or transnational identities that undermine the idea of divided space, which borders represent and symbolize. In the recent social research, one had articulated the concept of "transnational" in order to explain how the migrants and displaced persons react in relation to their respective homelands. (Božić: 2004, 187-203). As a matter of fact, some ethnic groups are not territorially bound; they can be dispersed or behave

59 Cf. on this still very valuable book by A. L. Kroeber \& Clyde Kluckhohn: Culture: A critical review of concepts and definitions, New York, Vintage Books, 1963. Also: C. Geertz: Religion as a cultural system, in: M. Banton (ed.): Anthropological approaches to the study of religion, London, Tavistock, pp. 1-46 and his: The interpretation of cultures, New York, 1973.

6o This categories are to some extent parallel to those developed by Robert Redfield in 1941 . He distinguished between folk society as an isolated, nonliterate $\&$ homogenous group with a strong sense of solidarity and the modern urban society. Another polar constructions of this kind can be found in sacred-secular (Becker), familistic-contractual (Sorokin) and a traditional-modern dichtotomies.

61 Cf. the works cited in the note 2. The older contributions contained in the special issue of the former Belgrade review "Gledišta": Etnos, narod, nacija", Gledišta, 24 (1983), 1-2, str. 3.-241. are still very instructive on this point. 
according to the supra-national loyalties. One can also speak of a fluid, uncertain or "frontier transcending (Grenzüberschreitende)" loyalties. In particular, religious groups can eventually be conceived as meta-ethnic or even meta-national communities. This has been an essential feature of the Middle Ages and Early modern times in Europe, when religious identity was far more important than the linguistic or territorial one. After that, since the French revolution, simultaneously with secularization religions and ethnicity gave way to processes of wider identifications with the nation-states. Still, in some particular cases (Ireland, Poland and Croatia) religion kept its place as a symbolic marker of the national identity. Recently, in the contemporary world, Islamic tradition based upon the concept of the community of believers (the Umma), God's law (al-Sharia) and that of a holy-war (djihad), has taken various forms of radicalization. It has been observed that many individuals living in Europe, who are part of the Islamic community, relate less to their ethnic origins, than to a sense of belonging to a wide global community of Islamic believers. As such, jihadism as a form of political violence and terrorism could be viewed not only as a kind of sub-culture or counterculture, but principally as a manifestation of a transnational identity (Ahmed \& Pisoiu, 2017, 161-174 and Kumpes, 1990, 184-192).

On the other hand, a lot of ethnic identities are prone to fluctuations and the self-image of a particular group can alternate from passivity to a euphoric state. We may speak of processes of assimilation, marginalization and extinction of particular ethnic groups in history and even in the contemporary world. Thus, since the antiquity, many groups have been absorbed into larger surrounding identities. Such was the case of the oldest Balkan population - the Illyrians, which played the important part in the ethno genesis of several Balkan peoples.

The most puzzling is probably the so-called "Vlach" group whose origins and later destiny remain a mystery even after the decades of the research on this topic. Vlachs or the Aromanians ${ }^{62}$ have remained as an autonomous ethnic entity during the centuries, but seldom gained recognition as such. Recently, they have been recognized as a national minority in Serbia, but in Greece and Romania they have not gained recognition as an independent ethnic group. Given the linguistic parenthood, their idioms in Macedonia and Albania belong to the Romance languages, being developed from the vulgar and medieval Latin vernacular, spread in the Balkans and in the South-east Europe, after the Roman conquest. It is questionable whether actual Arumanian group in Macedonia could be treated as an ethnic fragment or as belonging to one of the groups threatened by extinction. ${ }^{63}$

4.4. Besides ethnic, national and transnational identities, one can also focus on the processes of border constructions, including symbolic markers and rituals which constitute what can be called "bordering" practices. Bordering practices in a wider sense may encompass various activities of material and physical nature; military presence, access to the markets and

62 Cf. Zef Mirdita: Vlasi u historiografiji, Zagreb, 2004. According to the Croatian geographer Branimir Gušić, "Morlaks" as a western branch of Vlachs, emerged within a symbiosis between ancient Illyrians and the Roman settlers, containing strong paleomeditearean and Slavic elements. Cf. B. Gušić: Wer sind die Morlaken? Balcanica, IV (1973), 453-464, quoted in Mirdita, op. cit., p. 348, N73. Orthodox settlers in the former Croatian Military frontier (Vojna Krajina) initially officially registered under the "Vlach" designation, have later constituted the main part of the Serbian minority in Croatia.

63 Recently, Karl-Markus Gaus referred to Sephardic Jews from Sarajevo, the Germans in the Kočevje (Gottschee) region in Slovenia, Albanian minority group in Italian Calabria, Lusitan Sorabs (eastern Germany) and finally, Macedonian Arumanians as the ethnic groups in the way of extinction. Cf. his: Europljani u izumiranju, Zagreb, 2010 (originally published as: Die sterbende Europäer, Wien, Paul Zsolnay Verlag, 2001). Milenko Filipović, a distinguished Serbian ethnographer, has already before the World War II, noticed a declining pastoral way of life among Arumanians on the eastern Macedonian border (Nomadski Cincari na Ograždenu, Glasnik geografskog društva, 24, 1938., str. 59.-72.). On the language extinction, cf. Atlas jezika, op. cit., (N2), 208.-217. 
water resources, building walls and barriers, erecting of safe passages and finally, clandestine activities such as smuggling. But, bordering also denotes symbolic practices as a kind of cultural management and political technology belonging to a mode of governmentality. It is shown in erection of symbolic markers such as border stones, monuments, rising state flags, performing holiday celebrations, commemorations and other religious and secular rituals.

Although the concept of ritual derives from the religious practices (liturgy, celebration of saints etc.) it can take also a secular form. ${ }^{64}$ Most European folk customs can be seen as rituals belonging to the rites of passage and the annual holiday cycle, but are usually associated with religious holidays. But, since the 1789 revolution a secularized form of rituals have appeared in France in order to supplant or replace folk and religious traditions. Similarly a century later, in the Soviet Union and afterwards in other Communist states, including Yugoslavia, official policies attempted to replace traditional religious and popular usages with the new socialist one, hindering church attendance and religious performances.

One of the significant bordering practices relates to the process of naming, i.e. name giving to the cities, streets and geographical locations in general. Some of these practices are related to the external border changes i.e. the displacement of the state frontiers, while the others are performed in the function of internal power politics as instruments of control and governance. Therefore one can distinguish, naming as reference to the nation-state identity and sovereignty (external function) from the name giving in the process of defining of normative order upon official ideological meanings (internal cultural management). After the Second World War, and with establishment of the new state frontiers, older names of urban and rural settlements as well as those of the whole regions have been replaced by the new administrative designations, in accordance with the new official language or prevailing cultural traditions. This changes have been considerable in the former German territories in the east (eastern Prussia, Baltic coast, borderlands along rivers Oder and Neiss including old German cities of Breslau and Stettin) taken by Poland and the Soviet Union. Consequently, the names of the local settlements have been changed, taking forms conform to the new official language or re-invented. ${ }^{65}$ In Italy, after the First World War, names of the localities in South Tirol (Alto Adige) and those in the newly acquired eastern cities and provinces have been Italianized. Moreover, many city streets and squares names in Italy often refer to former Italian possessions on the eastern Adriatic or otherwise appeal to the patriotic and irredentist sentiments. ${ }^{66}$

64 Cf. M. Agulhon: Marianne au combat, Paris, 1979; R. Firth: Symbols: Public and private, London, 1973; C. Lane: The rites of rulers: Ritual in industrial society - The Soviet case, Cambridge, 1981; S. F. Moore \& B. G. Myerhoff: Introduction: Secular ritual, in: S. F. Moore/B.G. Myerhoff (eds.): Secular ritual, Assen, 1977, pp. 3-24 and M. Ozouf: La fête révolutionnaire, 1789-1799, Paris, 1976. Literature on customs as a part of the traditional South Slav folklore is considerable and cannot be cited here. Cf. for instance M. Gavazzi: Godina dana hrvatskih narodnih običaja, 2nd. ed., Zagreb, 1988. (1939).

65 So for instance, the place of birth of the famous philosopher Immanuel Kant-Koenigsberg has been named Kaliningrad. This part of Eastern Prussia incorporated into Soviet Union after World War II, and now belonging to Russia, is officially called "Kaliningrad area" (Kalinigradska oblast).

66 Cf. for instance: M. Isnenghi: La piazza italiana, in: M. Isnenghi (ed.): Luoghi della memoria: Strutture ed eventi dell'Italia unita, Bari, Laterza, 1997, pp. 41-52. One of the main squares in Trieste is thus named according to a martyr of the irrendentist cause (piazza Oberdan). For the anthropological reflexion on the impact of political symbolism of the street names, monuments and holidays, cf. D. Rihtman-Auguštin: Ulice moga grada: Antropologija domaćeg terena, Zemun/Beograd, 2000. She explores in particular, how the city spaces have been transformed during the new national identification in the post-1991 Croatia, shown in the changing street names and in the erection of monuments and memorials. 
From the point of view of the "internal" cultural management, as a part of symbolic process of naming during Communist rule, one can particularly point out to the frequent practices of changing not only street names, but also that of cities and regions. Following this Soviet Russian style, all Communist countries sought frequently to denominate local places according to the distinguished persons and leaders of the revolutionary past. Thus, the former Russian capital Petrograd became Leningrad; it reverted to its ancient name, only after the fall of the regime, becoming actual Sankt Petersburg. But, in some cases, even the whole cities have disappeared from the maps being absorbed into new administrative ordering. ${ }^{67}$

\section{IDENTITIES AND RIGHTS. STATUS, CITIZENSHIP AND GROUP BOUNDARIES}

5.1. Moreover, if borders are understood not only through presence of barriers in the physical space, but also in a wider sense, as bordering and ordering processes, then it is possible to speak about liminal practices in the construction of social space. In this sense, one can distinguish between legal-territorial understanding of "borders" on one hand, and the "boundaries" as the limit-lines of collectivities, on the other. Consequently, bordering positions of individuals and groups can be described in terms of inclusion and exclusion processes within social world. But, such lower and higher social positioning often depends on arbitrary evaluation and selection criteria.

Thus, the study of borders and that of bordering practices as a way of creation of boundaries and distinctions is also relevant on the micro-level of analysis, i.e. in the investigation of the position of individuals in the process of creating political and symbolic borders. In this context, one has to distinguish between social positions that are achieved or transmitted through spontaneous social processes and those, set up by law. In other words, one can distinguish between social status in the proper sense and the rights and obligations created by law (legal status). ${ }^{68}$ Citizenship and political rights are without doubt the most important part of the personal legal status in modern societies.

Although, international legal instruments refer in principle to the rights of minorities as collectivities, in practice they concern individuals, their educational and professional opportunities and basic rights, such as to use freely own language and to practice their religion. Therefore, the minority's issues cannot be properly investigated without reference to the individual life sphere and the personality development including life-chances. It should be stressed that besides ethnic, religious and linguistic minorities, European concept of human rights extends protection from various discrimination practices also to sexual minorities, i.e. so-called LGBT

67 The former border city of Sušak -a birth place of the writer Ödön von Horvath- was since 1947, joined to the city zone of Rijeka and as such disappeared from the maps. See the detailed study on Sušak's legal history by Željko Bartulović (2004), based upon his doctoral dissertation.

68 According to Black's Law Dictionary, status can be defined in terms of: "Standing, state or condition. The legal relation of individual to rest of the community. The rights, duties, capacities and incapacities which determine a person to a given class." (Black's Law Dictionary, rev. 4th. ed., St. Paul, Minn., 1968, 1580). 
persons. ${ }^{69}$ In this context, appears a "gender controversy" as implementation of non-discriminatory measures in this field meets strong opposition from traditionally oriented sectors of public opinion including the Catholic Church.

5.2. Social distinctions create the boundaries which determine access to wealth and a power in a given society and as such constitute a basis of social hierarchies, but also that of informal social interaction, marking the rules of etiquette in the interpersonal encounters. As such, social interaction includes norms of politeness, respect and courtesy, which are also part of legal culture. Etiquette represents, however, not only an informal artifact, but also a standard part of the official legal proceedings in domestic and international law. However, contrary to the ancient formal ways of paying respect to social superiors, in a modern society there is a great variety of encounters, which are carried out in a casual and informal way. Social interaction is nowadays directed by more subtle, informal, but nevertheless obligatory rules of the presentation of self. Some of this ways suggest existence of "rituals of interaction" as they are based upon standard and repetitive ways of the presentation such as wearing proper clothes, using right words and gestures etc. ${ }^{70}$

Social status criteria differ from pre-modern to modern societies and are as such studied in sociology and social history. According to Max Weber, there are three dimensions of stratification; property, prestige and power. Status groups based on the prestige create various life-styles and include professions, clubs, ethnic groups and similar associations. ${ }^{71}$ Another German sociologist, Georg Simmel has observed that in modern times, besides existence of "spatial, economic and mental boundaries", there are also increasing processes of "individuation", by which social personality expands and transcends narrower social bonds. ${ }^{72}$ Today, people increasingly communicate through the web, using also the apps and the low-cost gadgets. These new technologies seem to erode boundaries between personal and professional lives and even the sense of the real personal time and space.

Using the concepts of "cultural capital" and that of "aesthetic taste", French sociologist Pierre Bourdieu asserted that symbolic goods such as tastes in food, culture and presentation, already internalized at an early age, build the weapons in the social strategies of "distinction". ${ }^{73}$ For instance, people from the lower parts of social hierarchy chose "heavy, fattening and cheap foods", opting for "plentiful and good", while the upper groups prefer "original and exotic" products, fostering an ethics of sobriety and slimness. A difference between taste of luxury including freedom of choice and that of tastes of necessity reveals the cultural rift between the

69 The acronym means: Lesbian, Gay, Bisexual and Transgender/Transexual. Cf. E. Heinze: Sexual orientation: A Human right: An essay on international human rights law, Dordrecht, M. Nijhoff, 1995 and K. Waaldijk \& A. Clapham (eds.): Homosexuality: A European Community Issue: Essays on lesbian and gay rights in European law and policy, Dordrecht, M. Nijhoff, 1993. Interaction ritual, 1967).

72 He observed: "After the process of social differentiation has led to a separation between high and low, the mere formal fact of occupying a particular social position creates among the similarly characterized members of the most diverse groups a sense of solidarity and, frequently, actual relationships. Accompanying such a differentiation of social groups, there arise a need and an inclination to reach out beyond the original spatial, economic, and mental boundaries of the group and, in connection with the increase in individualization... to supplement the original centripetal forces of the lone group with a centrifugal tendency that forms bridges with other groups." (G. Simmel: On individuality and social forms: Selected writings, Chicago/London, 1971, p. 253.). 
social classes. Without wholly disregarding the importance of economic and social privileges, Bourdieu thus, stressed the status distinctions mainly as a product of cultural strategies.

5.3. The concept of citizenship (nationality) concerns the relationship between the individual and the state as a political community. It implies rights and duties of an individual person, in both internal and international law. ${ }^{74}$ Principles and norms of the international law in citizenship issues are particularly relevant in cases of state succession and the protection of human and minority rights. Citizenship is also of particular relevance in traditional forms of mobility control, which were in the past coupled with the "invention of the passport" (Torpey, 2000).

Moreover, if we consider the nature of citizenship in the perspective of the relationship between public and private spheres, citizenship appears then, as one of the key mechanism in this context. It serves as one of the basic techniques of inclusion-exclusion processes within the political realm. In the period after the Enlightenment, the rights of citizenship have evolved in order to include civil, political and social rights. Thus, since the French revolution in 1789, the concept of "citoyen" appears as the civic republican concept of citizenship. ${ }^{75}$ Contrary to the traditional notion of a state subject, with differentiated socio-legal statutes, civic citizen concept includes reciprocal responsibilities of the equal members of a political community. Still, the minors, women, migrants and minorities were before, and are even today, excluded from the role of active political actors.

There are generally speaking, two basic ways of the acquisition of citizenship; by origin and by naturalization. Also, from the legal point of view there are two basic criteria for the acquisition of citizenship at birth: so-called ius soli and the ius sanguinis principles. While the first one (common in the USA and France) privileges the territory (law of soil), another one (traditionally prevalent in Germany and in the most of European countries), takes into account the parent's affiliations of the child (common descent). Moreover, a lot of countries distinguish between the regular and privileged (preferential, facilitated) ways of acquiring citizenship. In addition, some countries also know special procedures of naturalization which is granted to the individuals who do not need to fulfil usual requirements of the regular and privileged naturalization. ${ }^{76}$ Usually, the naturalization is performed in the application of the administrative procedure known as "discretionary or free decision" (freies Ermessen; pouvoir discrétionnaire). In theory, administrative decision of this kind is guided by the principle of public interest, which in judicial cases is also known as the reference to the "ordre public", according to the French term relating to the doctrine of constitutional guaranties. ${ }^{77}$

74 Cf. Encyclopaedia of Public International Law, VIII., 1985, 419-420.

75 Cf. J. Habermas: Citizenship and national identity, in: B. Van Steenberghen (ed.): The condition of citizenship, London, Sage, pp. 20-35 and D. Heater: What is citizenship? Cambridge, Polity Press, 1999.

76 Such was for instance the provision contained in the Slovenian law, where it was stipulated that aliens could be admitted to citizenship on the ground of cultural, economic, national and similar reasons (The Official Gazette of the Republic of Slovenia, 1/91-1, 30/91-1, 38/92).

77 According to G. Drago: “(...) l'ordre public peut être défini comme une notion qui encadre et, à la fois, légitime l'action des pouvoirs publics L'ordre public s'exprime... par des exigences de securité publique, au sens le plus classique... qui soi: sûreté, protection des personnes et des biens..., ou encore lutte contre la fraude... Ensuite. Il tend à assurer la garantie effective des droits et libertés constitutionnelles." (L'ordre public et la Constitution, Archives de philosophie du droit, 2015, 199-214, pp. 199 and 203). 
Particular British practices of border and immigration controls have also been reflected into citizenship regulations. So, the procedure to become British citizen has also included so-called registration in difference to the regular naturalization. This concerned residents of British dependent and overseas territories. ${ }^{78}$

\section{EUROPEAN INTEGRATION \& THE UNION BORDERS. IMMIGRATION AND BORDER CONTROLS. REGIONS AND REGIONALISM}

6.1. The question of borders and identities can also be examined beyond the individual and collective spheres, across the limits of a nation-state, in a wider context of transnational, regional and global developments. As a matter of fact, in the recent history, new forms of the international cooperation have transcended existing geographical and cultural barriers. Thus, even if the vision of an integrated borderless global society did not took place in the world order, numerous forms of trans-border cooperation have been brought to life, establishing more or less durable economic, political and civil connexions. One of these achievements is the European integration, which was originally based upon four freedoms: free movement of persons, goods, capital and services. It emerged during the post-war tensions between East and West- described in terms of "cold war" and the "iron curtain" - symbolizing in particular, the spirit of "freedom" in the West, opposed to the new form of Oriental despotism in the East. Moreover, the idea of a new unified Europe across state frontiers, contributed in particular to the post-war French-German rapprochements (Monnet, Schuman, Adenauer), to the eradication of the traditional European rivalries containing representations of others as "enemies" and to the relativisation of nation-state borders.

Still, European Union remains until today as an unfinished project, a polycentric political community sui generis. According to some views, it is on the way to transform itself into a proto-imperial order with asymmetric relations between center and periphery. ${ }^{79}$ So far, the questions of the European culture and politics including language, history and law, have been widely discussed within the realms of political philosophy (Habermas), sociology and in the legal science, particularly in connexion with the constitutional law. In a sense, it could also be said that European project challenged established principles of the international law, such as sovereignty, territorial integrity and political independence. As a particular kind of the supra-national integration, EU faces many challenges which are threating its internal cohesion and pose several

78 In order to foster integration policies, the 2008 Green Paper issued by the Home Office, proposed the introduction of threestages in the process of naturalisation: temporary residence, probationary citizenship and as the end stage: acquisition of a full citizenship including right to the permanent residence. $C$. Home Office: The path to citizenship: Next steps in reforming the immigration system, quoted in: C. Bee \& D. Pachi: Active citizenship in the UK: Assessing institutional political strategies and mechanisms of civic engagement, Journal of Civil Society, 10 (2014), 1:100-117, p. 108. For the pre-Brexit era, cf. also: R. Hansen: Immigration and citizenship in post-war Britain, Oxford, OUP, 2000 and Home Office: Integration matters: A national strategy for refugee integration, London, 2005.

79 Cf. B. Kovačević: Tko je čuvar ustava u Europskoj uniji?, Politička misao, 50 (2013), 3:7-32. Medieval ius commune and the prospects of an unifying European law on a similar basis, have also been a much discussed topic among legal scholars. Cf. for instance: R.C. van Caenegem: European law in the past and the future: Unity and diversity over two millenia, Cambridge, CUP, 2002. 
problems regarding its future. Besides legitimacy deficit regarding the decision-making, deficiencies of the labour market and social support, its relations with outside world, the enlargement project and particularly the problems of immigration, increase the feelings of insecurity and fear.

6.2. It was customary in the past decennies to see the creation of European citizenship as one of the ways for the establishment of a common European identity and a convenient mechanism for the future transformation of the united Europe into a more cohesive democratic political union. Union citizenship was first introduced by the Maastricht Treaty and amended in the Treaty of Amsterdam. It was also laid out in the European Charter of fundamental Rights signed in Nice in December $2000 .^{80}$ At the outset, the aim of citizenship was to foster popular support and allegiance to the EU institutions, especially in view of existing democracy deficit. It confers rights of movement, political rights, rights to petition and the extra-border protection, to all nationals of the member states.

In theory, it is linked to the idea of a "republicanism", as a reference to the civic (political) commitments, contrary to ethno-national ones. For Habermas, the concept of "constitutional patriotism" is an answer to the difficulties of conceiving political identity that is neither liberal or anti-liberal, nor individualist or communitarian.

It has been observed that the EU citizenship "has an anaemic content, and/that/its future function remains unclear and contested, beyond the explicit claim that it shall complement rather than replace national citizenship". ${ }^{81}$ Therefore, it is questionable whether this concept has a valid empirical content, besides a mere normative value. Still, it represents a new reference in the socio-legal context of the Union, giving rise to the feelings of transnational and post-national identities. As a matter of fact, a major practical achievement of the European citizenship represent internal mobility rights, which enable citizens of the member states to move freely, to study, to work and to enjoy social benefits in other member states.

6.3. One of the salient characteristics of the European political and institutional development has been the standardization of rules regarding border controls. In this context, one has to distinguish between control policies at the entry to the EU, and that in the interior of the Union, i.e. between external and internal borders. Basically, European border practices and institutional arrangements appear as complex and are subject to the rising controversies among member states, on one hand, and between EU and other states, on the other. Actually, border policies have become a particularly sensitive issue as the rules and procedures governing admission of foreign nationals are increasingly contested especially by the countries of entry which feel unable to deal with migration flows and to fight illegal immigration. ${ }^{82}$

Actual external border system in Europe is essentially built on two union arrangements, precisely the Schengen Agreement in 1986 for migratory policy and 1990 Dublin Convention for asylum and refugee policy. From the institutional point of view, control and surveillance

80 Cf. A. Follesdal: Union citizenship: Conceptions, conditions and preconditions; Union citizenship: Unpacking the beast of burden, Law and Philosophy, 20, 2001, 233-237 and 313-343. Also: P. B. Lehning: European citizenship: Towards a European identity?, Law and Philosophy, 20, 2001, 239-282.

81 A. Follesdal: Union citizenship: Unpacking the beast of burden, op. cit., p. 314.

82 Cf. the contributions by M. Lovec: Politics of the Schengen/Dublin system: The case of the European migrant and refugee crisis and M. Borkert: The border within: Immigration policymaking in Europe and the role of science, in: Günay/ Witjes (2017, 127142 and 195-212). Also: S. Sommer: Opening fortress Europe? Constructing a new approach to EU migration policy, Brussels Journal of International Studies, 10, 2013, 42-92. 
system of the EU consists of an array of several agencies and mechanisms; FRONTEX, (the agency for the cooperation at the external EU borders), EUROPOL, Rapid Border Intervention Teams (RABIT), the Mediterranean Coastal Patrols Network (MEDSEA), the Schengen Information System (SIS), the European Border Surveillance System (EUROSUR) and the European Dactylo-scopy (EURODAC). The last name refers to the fingerprint database which is used mainly for identifying asylum seekers and migrants in general. ${ }^{83}$

6.4. Contemporary border controls in Europe do not extend only to the frontier checks and to the traditional use of passports and travel documents. They concern nowadays expanding use of advanced, sophisticated systems of mobility surveillance developed by the information and communication technologies (ICT). As it is well known, modern technology (computers, digital photography, scanners) may facilitate body controls, but they also provide means for the falsification and forgery of identity papers.

The advancement of digital systems has become the basis of the EU official border policies and led to the establishment of three kinds of digital data bases. ${ }^{84}$ The first one, the Schengen Information System (SIS), allows access to data concerning persons for arrest, those subject to an entry ban and those who are under surveillance. The introduction of this system was motivated by the concerns to fight cross-border criminality and has been negotiated for some time before the implementation, which was postponed several times because of various technical, political and legal issues.

The second database called EURODAC (European dactyloscopic) aims at control of persons who do not have a visa and enter into a refugee's asylum procedure. This central registration system stores and compares recorded fingerprints with a place and time of the prints, providing details about the admission application. EURODAC serves essentially as an instrument to determine which member state is responsible for a refugee's asylum admittance according to the Dublin Convention. As such, EURODAC has been a reaction to the migrant crisis of the late 1990s, when the potential asylum seekers claimed asylums in different countries.

The Visa Information System (VIS) is the third operational data base introduced in 2011 in order to facilitate data exchange between the member states concerning visa applications. It aims principally to investigate and prevent terrorism and to foreclose overstay in the EU of persons whose visa has expired ("overstayers"). This database collects standard alpha-numeric data allowing also use of biometric finger and body prints. In 2011, these systems were joined into the newly established European Agency for the operational management of large-scale IT systems (eu-Lisa) in order to enable continuous exchange of data between member-states. According to the prevailing official views, it is possible to achieve safer Europe through technology, and ICT is nowadays considered as the most important ingredient of the mobility controls. ${ }^{85}$

As a result of these developments, one can conclude, that the actual evolution in border mobility supervision affirms the presence of two opposing trends; one, towards re-territoriali-

83 Cf. P. Hönig: States, borders and the state of exception: Framing the unauthorised migrant in Europe, Etnofoor, vol. 26 (2014), 1:125-145, p. 131.

84 Cf. P. Trauttmansdorff: The politics of digital borders, in: Günay/ Witjes (2017, 107-126).

85 One can cite in this sense, the following statement: "The vision of the future relies to a large extent on technology to improve security, convenience and cost-effectiveness in border control" (FRONTEX) and that of a former EU Commissioner , Franco Frattini, who said that there is no alternative to digitization (both quoted in P. Trauttmansdorff, op. cit., pp. 108 \& 112.). 
zation (reinforcement of fences and frontier controls) and another, fostering ex-territorialization (personal information gathering through digital technologies).

6.5. The term "region" refers to an elusive concept corresponding to the selective use of multiple criteria in the description of a given geographical space (Đulabić, 2007., 67.-73.; Britannica Online Encyclopedia, https://www.britannica.com/print/article/496048). Some authors have suggested to distinguish four concepts covered by this term: administrative, action, economic and cultural. As a cultural entity, it may refer to the native land (German: Heimat), while the other regional conceptions represent less structured space. ${ }^{86}$ Thus, while the term "area" usually signifies an arbitrary designation of the Earth's surface, "region" has a more precise meaning, as it is determined by its homogeneity and cohesiveness. According to diverse criteria or dominant features, it is customary to refer to topographical ("rain forest"), climatic, economic, political, ethnic, cultural, linguistic and administrative regions. Particular use of the term is found in the international politics and media, where appears the broad concept of regions, as the large sub-continental divisions (the Balkans, South-east Europe, Middle East, Central Asia, the Pacific area etc.).

Similarly to the multiple meanings of the word "region", the term "regionalism" is multi-vocal. Sometimes, it is used to describe international economic ties, interstate associations or groupings based on the region in a wider sense. It may be extended to designate inter-parliamentary organizations (Nordic Council), international public and private associations (Postal Union, GATT, NATO, IMF etc.). The European Union can be seen as a product of an international economic regionalism.

Usually, political regionalism denotes tendencies for the affirmation of sub-national entities (regions) delineated by cultural, ethnic, linguistic and other boundaries. Such projects may consist in the demands for a greater autonomy from the central state, claims for the decentralization policies or represent campaigns for independence and secession. In this sense, it is possible to distinguish "weak" (moderate) form of regionalism, from its "strong" forms. In a radical version, regionalism supports claims for self-determination of the people of the certain region or territory. Such claims may then lead to the secession. In the modern history, successful secessionist movements have appeared first in the former British and Spanish colonies, then in Europe (the Netherlands, Norway and Ireland). After the failed attempts at the secession of Québec, the self-determination demands are still a pending issue in Scotland and Spain, where Basque and Catalan nationalism remain on the agenda, and in France, where Corsica shows a state of permanent tension between central state authorities and the local separatists. But, some of the regional parties today seek to attain their goals with legal means, recognizing as legitime existing institutional arrangements such as parliaments and local government. Moreover, one has to distinguish regional parties from the "regionalist" ones, as some regional movements, like the Bavarian CSU, are closely integrated into nation's political mainstream. ${ }^{87}$ Nowadays, use of

86 Cf. B. Hammn: Vorwort: Bemerkungen zum Begriff der Region, in: C. Klein \& L. Krüger: Regionen in Europa, Trier, Universität Trier, 1998, p. 6. Cf. also entries: "Regije/Regionalizam" and "Regionalna politika" in: D. Nohlen (ed.): Politološki rječnik: Država i politika, Osijek, 2001. (transl: D. Nohlen/Hrsg./: Wörterbuch: Staat u. Politik, 4. Aufl., München, 1996).

87 In 1981, several democratic regionalist and nationalist parties agreed on the foundation of an association called "European Free Alliance (EFA)" with the aim to promote goals of the moderate "integrated regionalism" and to have greater impact on European affairs.The common platform of these parties consists into promotion of "cultural and linguistic rights, self determination, nation \& state building", but with pacific means. The Centre Maurits Coppieters Foundation created in Bruxelles, under the auspices of this associations is providing academic expertise on this and other questions, regarding stateless nations, mino-rities 
illegitimate violence and terrorism, present frequently in Ireland and Spain in the past, has given way to more conciliatory attitudes.

6.6. The concept of "region" in the EU belongs to the institutional design of the Union, which was elaborated principally in the 1980s, after the enlargement of the Union competencies and the admission of the new members. In the last decennies, regionalization has been promoted to one of the main goals of the Union's institutional development, in order that it was customary to speak about "Europe of the regions" ${ }^{88}$ There are several reasons for this stress on regionalization; first, it corresponds to the need for harmonizing economic and social development between member states, second, regionalization was directed towards a reduction of internal discrepancies within the states themselves, and third, the focus on regional policies derives- last but not least- from the concerns about political legitimacy of the Union, which was criticized for a presumed "democracy deficit". As a matter of fact, there are several principles and mechanisms that emphasize political participation in the EU. First is connected with the subsidiarity principle according to which it is convenient to transfer responsibilities for the decision-making on the lower levels of the institutional hierarchy. Second, introduction of the European citizenship and direct elections to the European Parliament may be seen as an important step towards more transparency and citizen's participation in the Union affairs.

Regional policies in Europe have been conducted by the EU and to a lesser degree by the Council of Europe (CoE), and the member states themselves. After the reform of 1988, the leading position in the common regional policy was taken by the European Commission, which set up numerous Community initiatives. As the financial instrument which have played a substantial role in the regional development, structural funds and later introduced Cohesion Fund, should be mentioned. ${ }^{89}$

One of the important achievements of the European regional policies has been the establishment of the interregional cooperation through trans-border cooperation and the macro-regional strategies. This "frontier-transcending" (German: Grenzüberschreitende Zusammenarbeit; French: coopération transfrontalière) cooperation has started at the beginning of the nineties with the Community initiative called INTERREG. Furthermore, special programme of cooperation has been promoted in 1994 regarding Central and East Europe (PHARE-CBC). For the Western Europe, one can cite as a particularly successful example of the transfrontier cooperation, the "Karlsruhe agreement" concluded on 23th January 1996 between Germany, France, Luxembourg and Switzerland, concerning cooperation between local self-governments and other public bodies. ${ }^{90}$ A large framework for interregional and international cooperation- as they concern

and regions. Cf. the EFA publication: European Free Alliance: Who is who? s.d, and info@cmc-foundation.eu/; www.ideasforeurope. eu. See also the Table: Regional parties and movements in Europe, infra.

88 On the European regional concepts and development $c f$. some older, but still valuable contributions: G. Ammon: L'Europe des régions, Paris, Economica, 1996; D. Harhues: Europa der Regionen: Zwischen Vision u. Wirlickheit, Münster, WWL, 1996; P. Le Galès \& C. Lequesne (eds.): Les paradoxes des régions en Europe, Paris, La Découverte, 1997 and H. Siedentopf et alii (eds.): Europäische Regionalpolitik, Baden-Baden, Nomos, 1997. For the Croatian contributions, cf. Đulabić (2007., 102.-144.), and I. Koprić: Contemporary Croatian public administration on the reform waves, Godišnjak Akademije pravnih znanosti Hrvatske, 2 (2011), 1:1.-39., accessible on: URL htpp://hrcak.srce.hr79893.

89 For the development of Union's regional policies cf. already mentioned works (supra).

90 Cf. the full text in: A. Bußmann: Die dezentrale grenzüberschreitzende Zusammenarbeit mit Deutschlands Nachbarländern Frankreich und Polen: Zur möglichen Übertragbarkeit des Karlsruher Übereinkommens auf die deutsch-polnische Grenzregion, 
also non-EU countries- has been provided by macro-regional strategies (MRS). The first MRS was proclaimed in 2009, encompassing the Baltic Sea Region (EUSBSR). Another agreements, related to the Danube Region (EUSDR) in 2011, then to the Adriatic and Ionian Region (EUSAIR) in 2014. More recently, the Alpine Region (EUSALP) has been launched in $2015 .{ }^{91}$ Transfrontier cooperation appears as particularly beneficial for borderlands, as it provides further points of contact over the state frontiers, borders being often counterproductive for the development of economic and cultural exchanges between populations in the frontier area.

Region and regional development have lately become fashionable and a much discussed topics in sociology, political, legal and administrative sciences. In particular, regional development concepts have been elaborated in administrative science, regarding decentralization, administrative reforms and transition countries. In general, reflexion on the future of public administration in a changing and increasingly complex world has yield into several doctrines or paradigms, regarding public management and public policies. Thus, besides classical Weberian model of the rational bureaucracy, another influential paradigms have appeared such as neo-institutionalism, new public management (NPM) and good governance. ${ }^{92}$ It can be said that the solutions proposed in these theoretical approaches have not yet proven to become efficient means of the reconciliation of the public and private interests, as the praxis of decentralization reforms and the so-called public-private partnership shows. In the transitional countries as well as in those on the European periphery (the Mediterranean), administrative reforms clash with poorly formulated and outdated regulations, low level of ethical standards and various meta-legal influences such as corruption, clientelism and patronage. Local and regional administration is according to some views, professionally deficient being too much politicized, what is reinforced by some legal changes such as the introduction of the direct election of mayors. There are also growing concerns about environmental damages, space and biosphere degradation.

In order to set up a genuine and more citizen-oriented regional policy, it is necessary - in our view - to take firstly, into consideration the citizens needs on the local and regional level. Secondly, a profound analysis of the tasks and initiatives which can be provided by the public and private bodies should complement a new strategy of local and regional development. As a matter of fact, tasks and services provided by local institutional framework including private and public bodies are manifold. They can be roughly divided into three groups: communal services regarding physical infrastructure, human services and local regulatory tasks. ${ }^{93}$ In this analysis, it would be necessary to reconcile local historical identities with administrative rationality, bearing in mind that the municipal level of governance, whether highly fragmented or not, cannot provide adequate means for the improvement of highly specialized services such as education, hospitals, medical services, child and aging-population care.

Baden-Baden, Nomos, 2005, pp. 285-302. The Karlsruhe agreement concerns besides Luxembourg, the following German "Länder": Baden-Württemberg, Rheinland-Pfalz and Saarland, then in France region Alsace (Elsass) and region Lorraine (Lothringen), and in Switzerland, the following cantons: Solothurn (Soleure), Basel-Stadt, Basel-Landschaft and the canton Jura.

92 For the theoretical frame of the administrative science analyses, $c f$. I. Koprić: Contemporary Croatian public administration on the reform waves, op. cit., esp. pp. 3-9.

93 Cf. K. Davey: Decentralization in CEE Countries: Obstacles and opportunities, in: Gabor Peteri (ed.): Mastering decentralization and public administration reforms in Central and Eastern Europe, 2nd ed., Budapest, Open society institute, 2003, 33-41. Tasks relating to communal services usually include roads, lighting, water supply, waste management, heating, sanitation and other services besides housing management. Human services encompass the fields of education, health, social welfare and culture, while the local regulatory tasks relate to civil registration, trade and occupational licensing, child protection and construction control. 
In conclusion, it could be asserted that a region could in the future become a privileged forum for the expression of citizen's needs and aspirations, enabling their involvement into local and regional affairs.

Table - Regional parties and movements in Europe

\begin{tabular}{|c|c|c|}
\hline STATE & PARTY or MOVEMENT & LOCATION \\
\hline AUSTRIA & Enotna lista; & Klagenfurt \\
\hline BELGIUM & $\begin{array}{l}\text { NVA-Nieuw-Vlaamse Alliantie; } \\
\text { PRODG }\end{array}$ & $\begin{array}{l}\text { Brussel; } \\
\text { Eupen; }\end{array}$ \\
\hline BULGARIA & Omo 'Ilinden' Pirin & Pirin \\
\hline CROATIA & $\begin{array}{l}\text { *IDS; } \\
\text { Lista za Rijeku; } \\
\text { *PGS }\end{array}$ & $\begin{array}{l}\text { Pula; } \\
\text { Rijeka; } \\
\text { Rijeka; }\end{array}$ \\
\hline CZECH REPUBLIC & Moravane & Brno \\
\hline DENMARK & Schleswigsche Partei & Aabenraa \\
\hline ENGLAND (Cornwall) & Mebyon Kernow & Truro \\
\hline FINLAND & Ålands Framtid & Mariehamn (Åland) \\
\hline FRANCE & $\begin{array}{l}\text { MRS-Mouvement Région Savoie; } \\
\text { Partit Occitan; } \\
\text { PNC-Partitu di a Nazione Corsa; } \\
\text { Union Démocratique Bretonne; } \\
\text { Unitat Catalana; } \\
\text { Unser Land; }\end{array}$ & $\begin{array}{l}\text { Morzine (Savoie); } \\
\text { Romasieras; } \\
\text { Bastia; } \\
\text { Saint-Brieuc; } \\
\text { Perpinya; } \\
\text { Ensisheim (Elsass/Alsace); }\end{array}$ \\
\hline GERMANY & $\begin{array}{l}\text { Bayern Partei; } \\
\text { Die Friesen; } \\
\text { SSW-Landes-Verband; } \\
\text { Lausitzer Allianz; }\end{array}$ & $\begin{array}{l}\text { München; } \\
\text { Leer (Ostfriesland); } \\
\text { Flensburg; } \\
\text { Cottbus; }\end{array}$ \\
\hline GREECE & Rainbow & Florina/Lerin \\
\hline ITALY & $\begin{array}{l}\text {-Alpe; } \\
\text {-**Lega Nord } \\
\text {-Liga Veneta Repubblica; } \\
\text {-Partito Sardo d'Azione; } \\
\text {-Slovenska Skupnost; } \\
\text {-Süd-Tiroler Freiheit; }\end{array}$ & $\begin{array}{l}\text { Aosta (Valle d'Aosta) } \\
- \\
\text { Alpo (VR-Veneto); } \\
\text { Cagliari (Sardinia); } \\
\text { Trieste; } \\
\text { Kaltern a.d.W. (Süd-Tirol); }\end{array}$ \\
\hline LATVIA & FHRUL/PCTVL & Riga \\
\hline (The) NETHERLANDS & FNP - Fryske Nasjonale Partij & Ljouwert/Leeuwarden \\
\hline POLAND & RAS-Ruch Autonomi Slaska & Katowice \\
\hline SCOTLAND & Scottish National Party & Edinburgh \\
\hline SLOVAKIA & SZS-Strana živnostnikov Slovenska & Košice \\
\hline SPAIN & $\begin{array}{l}\text {-Aralar; } \\
\text {-Bloque Nacionalista Galego; } \\
\text {-Chunta Aragonista; } \\
\text {-Eusko Alkartasun; } \\
\text {-Esquerra Republicana de Catalunya; } \\
\text {-Partido Andalucista; } \\
\text {-PSM-Entesa Nacionalista; } \\
\text {-Bloc Nacionalista Valencia; } \\
\text {-Nueva Canarias; }\end{array}$ & $\begin{array}{l}\text { Irunea; } \\
\text { Santiago de Compostela; } \\
\text { Zaragoza } \\
\text { Donostia Gipuzkoa; } \\
\text { Barcelona; } \\
\text { Sevilla; } \\
\text { Palma (Illes Balears); } \\
\text { Valencia; } \\
\text { Canaria (Islas Canarias); }\end{array}$ \\
\hline WALES & Plaid Cymru & Cardiff \\
\hline
\end{tabular}

Source: European Free Alliance: Who's who? s.d. and various newspaper reports.

* Not members of the EFA (European Free Alliance). ${ }^{* *}$ Lega Nord was expelled from EFA in 1998. 


\section{CONCLUSION}

Besides conventional image of state borders as the national space delimitations, borders and boundaries could also be seen as the mental maps, which - following Foucault - represent deep structures of thought, which may also constitute transient cultural artefacts. As such, boundaries in the most general sense, construct social and individual identities, public and private as well as they contribute to the various institutional practices.

The state borders have been conceived with the emergence of international law especially after the Westphalian peace settlements in 1648, as lineal delimitations of state's territories conceived as national space. They were considered as the marks of state's territorial integrity and sovereignty. Since then state territory appears as a cohesive entity divided from the neighbors by clear geometrical lines. Besides arguments in favour of self-determination and linguistic divisions, claims to border acquisitions and revisions have been also based upon the idea of "natural borders". But, the border areas were also considered as buffer zones, which should contain foreign influences and enable better control of the local population with questionable loyalties. The buffer zone function was also the protection of the domestic economy threatened by illegal trade and not-supervised traffic of people and goods.

In the 19th and 20th centuries, as examples of France and Italy show, the building of the modern nation-states in Europe, also kept up with nationalist feelings aimed at the annexation, liberation and incorporation of the disputed territories. Besides, the conquered -ethnically alien population -has also been subject to the forcible integration and assimilation, particularly noticeable in the newly acquired Italian territories with the rise of the fascism. In the Balkans and in Turkey, the consolidation of the new nation-states has been occasionally accompanied by the forcible re-settlement of ethnic groups and minorities. Among other similar examples of this border consolidation policies one can cite expulsion of several millions of ethnic Germans from the newly acquired territories of Poland and the Soviet Union after the end of World War II. It is also known that many Italians have left Adriatic parts of Yugoslavia after 1947 in order to join their homeland or to emigrate abroad, what altered considerably ethnic composition of some cities, especially in the Istrian region.

The backbone of many territorial aspirations in the past, were imperial designs and irredentist ideologies. Already developed and realized by Britain and France together with some smaller nations like Portuguese and Dutch, these aspirations were aimed at the conquest of colonies and over-seas possessions. But, the idea of the millenarian Reich in Germany corresponded with older geopolitical considerations about "living space" (Lebensraum). In Italy, imperial designs connected irredentist ideology in the wake of Risorgimento with the reminiscences of the glorious Roman past, in order to build up the new Roman Empire, which had to extend to the whole Mediterranean and the parts of Africa.

During centuries and after the emergence of the modern nation-states, introduction of the official language, elite culture and the concept of citizenship led to the establishment of civic model of nationhood at the expense of the older traditional loyalties. They were situated around kinship, local customs and vernacular, folk beliefs and religion. Instead of them, elites in France for example, stressed the loyalty to the patrie and patriotism as the most important bond between citizens. National identity then appears as basic cultural construct of national 
consciousness, assembling images and symbols from the past and present into a meaningful whole. It becomes also the foundation stone of state's legitimacy and an instrument of political manipulation.

Contrary to the nation as the relatively modern phenomenon, ethnic groups could be seen as enduring entities which include also isolated religious and linguistic communities. They are bound together by the idea of common descent (blood), language or in some cases of religious distinction. Some of them have provided the core for the nation formation, but others have not escaped the historical destiny of being marginalized or absorbed into larger collectivities.

After the Second World War and with the process of European integration, the borders are not perceived only in terms of the nation-state, but also as the places of contact and exchange. Openness of state frontiers, especially after the free market and Schengen agreements, has largely contributed to the economic growth of economy and the development of infrastructure in the European borderlands. Also it should be added that contemporary European legal order presents especially through conventions and the practice of the Court of Human Rights in Strasbourg, various and efficient ways of protection of human rights and minorities.

Moreover, there have been also attempts to create poles of the cross-border interconnections in form of transnational regional entities. Rejection of the ethno-religious allegiances has been for a long time a feature of the cosmopolitan feelings and universalism based upon human rights concerns. Moreover, reflexion on the disastrous consequences of xenophobia, racial and ethnic persecutions, and armed conflicts has fostered the idea - already born in the Enlightenment - on the possibility of the emergence of a new world of openness, tolerance and multiculturalism. Also, the creation of the EU and the idea of globalization seemed to announce the end of history, the end of the nation-state and territorial-based identities. Yet in spite of the neoliberal economic linkages, that transcend local bonds and the state borders, the nation-state and the bordering practices will not disappear in the foreseeable future. With the massive migrations and the terrorism, it is obvious that there is a need for more border controls and consequently, several states have already revised their former policies of the border openness and exchange in order to control phenomena that are perceived as the security threats.

As the concluding remark, it could be said, that the reflexion on borders, appeals necessarily to an interdisciplinary approach, as it concerns not only politics and the state, but extends to the several aspects of social life, including institutional, economic, environmental and cultural developments. One can also agree with the Enver Hasani's remark that "borders are always artificial because states are not natural creations".

\section{LITERATURE}

\section{A) MONOGRAPHS, COLLECTIONS \& REFERENCE WORKS}

1. Jasna Adler, L'Union forcée: La Croatie et la création de l'état yougoslave (1918), Chêne-Bourg (CH), Georg Editeur, 1997.

2. Juraj Andrassy, Božidar Bakotić, Budislav Vukas, Međunarodno pravo. I.-II., Zagreb, Školska knjiga, 1995. 
3. Atlas Europe, Mladen Klemenčić (gl. ur.), Zagreb, Leksikografski zavod Miroslav Krleža, 1997.

4. Gerasimos Augustinos (ed.), The national idea in Eastern Europe: The politics of ethnic and civic community, Lexington (Mass.)/Toronto, D.C. Heath, 1996.

5. Ivo Banac, The national question in Yugoslavia: Origins, history, politics, Ithaca, Cornell Univ. Press, 1984.

6. Thomas Jefferson Barfield, The perilous frontier: Nomadic empires and China, Cambridge (Mass./ Oxford, 1989).

7. Fredrik Barth, Ethnic groups and boundaries:The social organization of culture difference, Michigan, IL, Little Brown, 1969.

8. Željko Bartulović, Sušak: 1919-1947: Državnopravni položaj grada, Rijeka, Pravni fakultet Sveučilišta, 2004.

9. Eberhard Bort (ed.), Borders and borderlands in Europe, Edinburgh, Univ. of Edinburgh, 1998.

10. Catherine Wendy Bracewell, The Uskoks of Senj: Piracy, banditry, and holy war in the sixteenth-century Adriatic, Ithaca, Cornell Univ. Press, 1992.

11. Chris Brown, Understanding international relations, 2nd ed., Basingstoke - New York, 2001.

12. Joshua Castellino, Steve Allen, Title to territory in international law: A temporal analysis, Aldershot, Ashhgate, 2003.

13. Emilio Cocco \& Everardo Minardi (eds.), Immaginare l'Adriatico: Contributi alla riscoperta sociale di uno spazio di frontiera, Milano, Franco Angeli, 2007.

14. Vladimir Dedijer, Pariska konferencija, Zagreb - Beograd, Biblioteka “Trideset dana”, 1948.

15. Franko Dota, Zaraćeno poraće. Konfliktni i konkurentski narativi o stradanju i iseljavanju Talijana Istre, Zagreb, Srednja Europa, 2010.

16. Vedran Đulabić, Regionalizam i regionalna politika, Zagreb, Društveno veleučilište u Zagrebu, 2007.

17. T. H. Eriksen, Ethnicity and nationalism, 2nd ed., London, Pluto Press, 2002.

18. Felipe Fernández-Armesto (prir.), The Times: Narodi Europe, Zagreb, Naklada Zadro, 1997. (Originally published as: The TIMES Guide to the peoples of Europe, London, Times Books, 1994).

19. John V. A. Fine, The late medieval Balkans: A critical survey from the late twelfth century to the Ottoman conquest, Ann Arbor, Univ. of Michigan Press, 1987.

20. Heather Ann Forrest, Protection of geographic names in international law and domain name system, 2nd ed., Kluwer, 2017.

21. Ivo Goldstein, Croatia: A history, London, Hurst \& Company, 2004.

22. Cengiz Günay, Nina Witjes (eds.), Border politics: Defining spaces of governance and forms of transgressions, Cham (Switzerland), Springer, 2017.

23. Peter Haslinger (ed.): Grenze im Kopf: Beiträge zur Geschichte der Grenze in Ostmitteleuropa, Frankfurt a. M., 1999 (Wiener Osteuropa-studien 11).

24. Waltraud Heindl, Edith Saurer (eds.), Grenze und Staat: Passwesen, Staatsbürgerschaft, Heimatrecht und Fremdgesetzgebung in der österreichischen Monarchie 1750-1867, Wien, 2000.

25. Egidio Ivetic, Adriatico orientale: Atlante storico di un litorale mediterraneo: Collana degli atti, Rovinj (Rovigno), Centro di ricerche storice, 2014.

26. Barbara Jelavich, History of the Balkans, Eighteenth and nineteenth centuries, I-II, .Cambridge, Cambridge Un. Press, 1983-1988.

27. Robert A. Kann, A history of the Habsburg empire, 1526-1918, University of California Press, 1980 (1974). 
28. Natko Katičić, More i vlast obalne države: Historijski razvoj, Zagreb, JAZU, 1953.

29. Henry Kissinger, Diplomacija, Zagreb, Golden marketing, 2000 (Diplomacy, Simon \& Schuster, New York, 1994).

30. Boris Krivokapić, Zaštita manjina u međunarodnom i uporednom pravu, Knj. I., Zaštita manjina: Istorijski razvoj, osnovna pitanja i zaštita u okviru Ujedinjenih nacija, Beograd, 2004.

31. Goranka Lalić Novak, Azil: Pravni i institucionalni aspekti, Zagreb, Pravni fakultet Sveučilišta, 2016.

32. Ivo J. Lederer, Yugoslavia at the peace conference: A study in frontier making, New Haven/London, University Press, 1963.

33. Tove H. Malloy, National minority rights in Europe, Oxford Univ. Press, 2005.

34. Cyril Mango, Byzantium: The empire of new Rome, London, Weidenfeld and Nicolson, 1980.

35. Zef Mirdita, Vlasi u historiografiji, Zagreb, Hrvatski institut za povijest, 2003

36. Jean Nouzille, Histoire de frontières: L'Autriche et l'empire ottoman, Paris, Berg, 1991.

37. Daniel Power, Naomi Standen (eds.), Frontiers in question: Eurasian borderlands 700-1700, Basingstoke/ London, 1999.

38. François Rigaux, Guerres et interventions dans le Sud-est européen, Paris, Ed. A. Pedone, 2004.

39. Dunja Rihtman-Auguštin, Ulice moga grada: Antropologija domaćeg terena, Zemun - Beograd, Biblioteka XX vek, Čigoja štampa, 2000.

40. Gerhard Seewann, Peter Dippold: Bibliographisches Handbuch der ethnischen Gruppen Südost-Europas, Band 1-2, München, Oldenbourg Verlag, 1997.

41. Georg Simmel, On individuality and social forms: Selected writings, Ed. and with an introduction by D. N. Levine, Chicago - London, The Un. of Chicago Press, 1971.

42. Simpozijum: Predslavenski etnički elementi na Balkanu u etnogenezi Južnih Slovena, Sarajevo, 1969.

43. Anthony D. Smith, Chosen peoples: Sacred sources of national identity, Oxford, OUP, 2004.

44. Dragoslav Šepić, Italija, saveznici i jugoslavensko pitanje, 1914-1918, Zagreb, Školska knjiga, 1970.

45. Alan John Percivale Taylor, The Habsburg Monarchy 1809-1918, The University of Chicago Press, 1976 (1941).

46. Bruno Tertrais /Delphine Papin: L’atlas des frontières: Murs, conflits, migrations, Paris, Les Arènes, 2017.

47. John Torpey: The invention of the passport: Surveillance, citizenship and the state, Cambridge, Cambridge Un. Press, 2000.

48. Stephen Tierney (ed.), Accommodating national identity: New approaches in international and domestic law, Kluwer, 2000.

49. Marija Todorova, Imaginarni Balkan, nadop. izdanje, Zagreb, Naklada Ljevak, 2015. (Imagining the Balkans, updated edition, Oxford Un. Press, 2009).

50. Elisabeth Vallet (ed.), Borders, fences and walls: State of insecurity? Ashgate, 2014.

51. Duško Večerina, Talijanski iredentizam, Zagreb, vlast. nakl., 2001.

52. Duško Vrban, Država i pravo, Zagreb, Golden marketing, 2003.

53. Duško Vrban, Sociologija prava: Uvod i izvorišne osnove, Zagreb, 2006.

54. Arthur Waldron, The great wall of China: From history to myth, Cambridge, 1990.

55. C. R. Whittaker, Frontiers of the Roman empire: A social and economic study, Baltimore - London, 1994. 
56. The World Book Encyclopedia, volumes:1-24, Chicago etc., World Book, Inc., 1996.

\section{B) ARTICLES, COLLECTIONS CONTRIBUTIONS \& COMMUNICATIONS}

1. Reem Ahmed \& Daniela Pisoiu, Beyond borders: Subcultural theory and the transnational Jihadi identity in Europe, in: C. Gunay \& N. Witjes (eds.): Border politics..., Cham, 2017, pp. 161-174.

2. Sandi Blagonić, Istrijanski regere fines: Tradicijska kultura i Balkan u diskurzivnoj konstrukciji identiteta, Problemi sjevernog Jadrana, 15 (2016) pp. 113-132.

3. Saša Božić, Nacionalizam - nacija, "transnacionalizam" -"transnacija": mogućnosti terminološkog usklađivanja, Revija za sociologiju, 35 (2004) 3-4, pp. 187-203.

4. Lea Brilmayer \& Natalie Klein, Land and sea: Two sovereignty regimes in search of a common denominator, International law and politics, vol. 33 (2001) pp. 703-769.

5. Walker Connor, When is a nation?, Ethnic and Racial Studies, vol. 13, 1990, 1, pp. 92-103.

6. Alexander C. Diener \& Joshua Hagen, Changing modalities of power in the twenty-first century, in: C. Gunay \& N. Witjes (eds.), Border politics..., Cham, 2017, pp. 15-32.

7. Didier Fassin, Policing boders, producing boundaries: The governmentality of immigration in dark times, Annual review of anthropology, vol. 40 (2011), pp. 213-226.

8. Lucien Fèbvre, Frontière: Le mot et la notion, in: L. Fèbvre: Pour une histoire à part entière, Paris, SEVPEN, 1962, pp. 11-24.

9. Milovan Gavazzi, Die kulturgeographische Gliederung Südosteuropas, Südost Forschungen, 15, 1956, pp. 5-21.

10. Erella Grassiani, Michiel Swinkels, Introduction: Engaging with borders, Etnofoor, vol. 26, 2014, 1, pp. 7-12.

11. Colin Heywood, The frontier in Ottoman history: Old ideas and new myths, in: D. Power/N. Standen (eds.), Frontiers in question: Eurasian borderlands 700-1700, Basingstoke/London, 1999, pp. 228-250.

12. H. van Houtum, The geopolitics of borders and boundaries, Geopolitics, 10, 2005, pp. 672-679.

13. Josip Kumpes, Refleksije o odnosu religije i etničkog identiteta, Gledišta, 1990, 3-4, pp. 184-192.

14. Matthew Lipman, Some aspects of Simmel's conception of the individual, In: K. H. Wolff (ed.), Essays on sociology, philosophy and aestethics, New York, pp. 119-138.

15. Marko Lovec, Politics of the Schengen/Dublin system: The case of the European migrant and refugee crisis, in: C. Gunay \& N. Witjes (eds.), Border politics..., Cham, 2017, pp. 127-142.

16. Marinko Lozančić \& Borna Fuerst-Bjeliš, Strategijska geografija: Odnos geografskog prostora i nacionalne snage (moći), Društvena istraživanja, 26 (2017), 2, pp. 269-289.

17. Vilim Matić, Ivan Stražemanac, Utvrđivanje granica početkom 18. stoljeća, Glasnik Arhiva Slavonije i Baranje, 5, 1999., str. 241.-256.

18. A. Paasi, Boundaries as social processes: Territoriality in the world of flows, Geopolitics, 3, 2007, 1, pp. 69-88.

19. “The Pact of London”, American Journal of Intern. Law- Supplement, vol. 13 (1919), pp. 436-440.

20. Sybille Reinke de Buitrago, The meaning of borders for national identity and state authority, in: $C$. Gunay \& N. Witjes (eds.), Border politics..., Cham, 2017, pp. 143-160.

21. Davorin Rudolf, Kratki pregled povijesti morskih granica u Jadranskom moru od dolaska Hrvata do danas, Zbornik radova Pravnog fakulteta u Splitu, god. 33, 1996., 43-44, str. 445.-452.

22. C. Rumford, Introduction: Theorizing borders, European Journal of Social Theory, 9, 2006, 2, pp. 155-169. 
23. Dragovan Šepić, Talijanski iredentizam na Jadranu: Konstante i transformacije, Časopis za suvremenu povijest, VII (1975), 1, str. 5.-32.

24. Petar Strčić, Egzodus Hrvata iz Istre i drugih hrvatskih krajeva između 1918. i 1958. godine kao politička, nacionalna i gospodarska pojava, in: Talijanska uprava na hrvatskom prostoru i egzodus Hrvata (1918. -1943.), Zagreb, 2001., str. 19.-60.

25. Seid M. Traljić, Tursko-mletačke granice u Dalmaciji u XVI. i XVII. stoljeću, Radovi Instituta JAZU u Zadru, sv. 20, 1973., str. 447.-458.

26. Paul Trauttmansdorff, The politics of digital borders, In: C. Gunay \& N. Witjes (eds.), Border politics..., Cham, 2017, pp. 107-126.

27. I. Van der Ploeg \& I. Sprenkels, Migration and the machine-readable body: Identification and biometrics, in: H. Dijstelbloem \& A. Meijer (eds.), Migration and the new technological borders of Europe, Hampshire, Palgrave Macmillan, 2011, pp. 68-104.

28. Budislav Vukas, Croatia and the law of the sea, Prinosi za poredbeno proučavanje prava i međunarodno pravo, vol. 24 (1996), 26, str. 13.-22.

29. Christian Windler, Grenzen vor Ort, Rechtsgeschichte, 1, 2002, pp. 122-145.

\section{C) INTERNET SOURCES}

1. Encyclopaedia Britannica Online, https://www.britannica.com.

2. Enver Hasani, Uti possidetis juris: From Rome to Kosovo, Fletcher Forum of World Affairs, Summer/Fall, 2003, http://pbosnia.kentlaw.edu/symposium/resources/hasani-fletcher.htm.

3. Thomas Höpel: The French-German Borderlands: Borderlands and nation-building in the 19th and 20th centuries, in: European History Online (EGO), published by the Leibniz Institute of European History (IEG), Mainz, 2012-08-23. URL: http://www.iewg-ego.eu/hoepelt-2012-en. 


\section{GRANICE KAO INTERDISCIPLINARNO PITANJE: TERITORIJALNOST I IDENTITET U PROŠLOSTI I SADAŠNJOSTI}

\section{Sažetak}

U radu se razmatra koncept prostora i teritorijalnosti u pravu i politici u odnosu na granice koje se smatraju ponajprije oblikom identifikacije i temeljem izgradnje nacije. Dok su u klasičnoj antici granice bile strukture u funkciji obrane, u modernom međunarodnom pravu 18. i 19. stoljeća one postaju prostori kojima države razgraničavaju suverenost svoga teritorija. Autor u radu razjašnjava simbolički značaj granica u suvremenoj europskoj povijesti vezano uz stvaranje imperija, nacionalistički diskurs i političke zamisli. U retorici granica često se naglašava teritorijalnu inkluziju i isključenost koje se oslanjaju na pojmove kao što su suverenitet, sigurnost i prirodni životni prostor ("prirodne granice"). Koncept granica također se odnosi na razumijevanje podjele Zemljine površine na područja definirana kao regije. Regije mogu činiti i prelaziti prirodne i političke granice. Iako su tijekom povijesti granice bile mjesta sukoba, one su bile i prostori povezivanje lokalnog i susjednog stanovništva. Borba za kulturnu i političku dominaciju kao i pokušaji integracije i asimilacije stanovništva koje živi uz granice, utjecali su na jezične politike vezane uz jezik uprave i javne sfere. Nakon Drugog svjetskog rata percepcija o granicama promijenila se i prevladalo je novo razumijevanje granica koje se temelji na ideji suradnje i priznavanju lokalnih tradicija i manjinskih prava. Načelo uti possidetis iuris primijenjuje se kako bi se spriječilo prekrajanje granica novonastalih država i kako bi se održala teritorijalna stabilnost regija. Međutim, nedavna migracijska kriza i sigurnosni problemi u Europi i Americi ponovno su aktualizirali percepciju državnih granica kao obrambenih struktura. Štoviše, uvođenje novih tehnologija, kao što su ICT i biometrika, mijenja klasične, linearne oblike nadzora teritorijalnih granica u mehanizme daljinskog nadzora i vladanja na daljinu.

Ključne riječi: $\quad$ granice, diplomacija, etnička pripadnost, granice (država), geopolitika, identitet, pomorske granice, sociologija prava, prostor, teritorij, simbolička politika 